\title{
HASANKEYF ER RIZK CAMISİ KORUMA VE KURTARMA (TAŞIMA) UYGULAMA ÇALIŞMALARI
}

\author{
Hasankeyf Er Rizk Mosque Conservation and Salvage (Relocation) Application Studies \\ Mesut YILMAZ ${ }^{1}$, Serap SEVGi ${ }^{2}$ \\ ÖZET

\section{ABSTRACT}

Tarih boyunca önemli bir yerleşim yeri olan Hasankeyf'in Dicle Nehri kenarındaki yerleşim alanı "Așağı Şehir" olarak adlandırılmaktadır. Hasankeyf' te günümüze ulaşan önemli taşınmaz kültür varlıklarını barındırmakta olan Aşağı şehir yerleşim alanın büyük bir bölümü, Ilısu Barajı ve Hidroelektrik Santralı (HEPP) Projesi'nin tamamlanmasıyla su altında kalma tehdidi ile karșı karşıya bulunmaktadır. Bu nedenle Hasankeyf’teki kültürel varlığın belgelenmesi, korunması ve kurtarılmasına yönelik kurtarma projeleri oluşturulmuştur. Bu proje çalışmaları uzun yıllar süren ulusal ve uluslararası profesyoneller, bilim insanlarımı, ilgili kurumların uzmanlarının (DSİ Genel Müdürlüğü ve Kültür Varlıkları ve Müzeler Genel Müdürlüğü) araştırmaları sonucunda her kültür mirasının özelinde yapısal durumu göz önüne alınarak tasarlanmıştır. Uluslararası profesyoneller ile teknik bilgi alışverişi sayesinde ülkemizin söz konusu teknolojide deneyim kazanması ve proje geliştirmesine katkı verilmiştir. Hasankeyf'te gerçekleștirilen yerinde koruma ve taşıma projelerinin kapsamında yer alan Er Rızk Camisi de yeni Hasankeyf yerleşiminde oluşturulan arkeopark alanındaki yeni yerine Bütüncül Taşınma Yöntemleri uygulanarak taşınmasıyla, baraj gölü suları altında kalma tehdidinden kurtarılmıștır. Er Rızk Camiinin 2019 yılında gerçekleştirilen koruma ve kurtarma (taşıma) çalışmaları, Birim yapı elemanlarına ayırarak taşıma, Bloklara ayırarak taşıma ve Strüktürel bütüncül taşıma yöntemlerinin birlikte uygulanmış az sayıdaki önemli proje örneklerinden birini oluşturmuştur. Bu makalede, Er Rızk Camsi'nin, taç kapının ve medrese hücrelerinin yer aldığı ve günümüzde cami olarak kullanılan kuzeydeki revaklı mekân kütlesi kendinden tahrikli modüler lastik tekerlekli taşıyıcıların (SPMT) kullanıldığı, "Strüktürel Bütüncül Taşıması" yöntemiyle, özgünlüğünü ve sağlamlığını en iyi şekilde koruyarak günümüze ulaşan bölüm olan minarenin ise "Birim Yap1 Elemanlarına Ayırarak Taşıması" yöntemiyle ve özgün harime ait kuzey cephe duvarının "Bloklara Ayırılarak Taşınması" yöntemi ile 4 yapı bloğuna ayırılarak taşınması detaylı olarak ele alınmıştır. Bu çalışma, ileriki süreçlerde, benzer biçimde yok olma tehdidi altında kalan tarihi ve kültürel mirasın kurtarılması çalışmalarına ve yapılacak bilimsel araştırmalara katkı sunma amacı taşımaktadır.

Anahtar Kelimeler: Barajlar, Kültürel Miras, Hasankeyf, Er Rızk Camsi, Bütüncül/Strüktürel Taşıma, Koruma.
Hasankeyf, which has been an important settlement throughout the history on the residential area by the Tigris River, is called the "Lower City". A large part of the Lower City residential area, which contains important cultural properties that have reached today in Hasankeyf, faces the threat of being flooded by the completion of the Ilisu Dam and Hydroelectric Power Plant (HEPP) Project. Therefore, salvage projects were created for documenting, conservating and saving the cultural properties in Hasankeyf. This project has been designed by considering structural situation of each cultural heritage in consequence of researches of national and international professionals, scientists and specialists of related institutions (DSI General Directorate of State Hydraulic Works and General Directorate of Cultural Heritage and Museums) for many years. Thanks to technical information exchange with international professionals, it is contributed to take experience about this technology and develop this project. Er Rizk Mosque, which is within the scope of in-situ conservation and relocation projects conducted in Hasankeyf, has been saved from the threat of being flooded by the dam, by applying Complementary Relocation Methods to its new place in the Archeopark Area created in the new Hasankeyf settlement. The conservation and salvage (relocation) applications of Er Rizk Mosque in 2019, constituted one of the few important projects that were applied together with the methods of transportation by "Separating into Unit Building Elements", "Structural Complementary Relocation" and "Relocation by Separating into Unit Building Elements" methods. In this study, in the Conservation and Salvage (Relocation) Project of the Er Rizk Mosque, which is conducted in 2019, relocation of the crown gate, the madrasah cells and the mass of portico in the north where uses as a mosque today by the "Structural Complementary Relocation" method using Self-Propelled Modular Transporters (SPMT), relocation of Minaret, which is the section that reached today by conserving its originality and stability in the best way by the "Relocation by Separating into Unit Building Elements" method and relocation of northern facade wall, which is belonging to the original harim by "Relocation by Separating into Blocks" method into 4 building blocks were discussed in detail. This study aims to contribute to the efforts to save the historical and cultural heritage, which are under threat of extinction, and scientific research to be carried out in the future.

Keywords:Dams, Cultural Heritage, Hasankeyf, Er Rizk Mosque, Structural/Holistic Relocation, Conservation.
1. Restoratör-Mimar-Sanat Tarihçi, Mesut Yılmaz, e-posta: yilmazmesut10@gmail.com

2. Yüksek Mimar, Dr. Serap Sevgi, e mail: serapsevgi06@gmail.com 


\section{EXTENDED ABSTRACT}

The studies that carried out by World Commission of Dams (WCD) on cultural areas where is under the dam reveal that the cultural properties where located in cultural heritage areas could not protect under water without any study about dams or lake water due to the water movements and ripple effect in a short time the immovable cultural properties. In addition, it is observed that bottom currents and culture layers in cultural heritage areas, which are softer than other natural fillings, cause destruction as a result of nesting of fish in the fillings. Therefore, the dams being built in the world and Turkey salvage the cultural heritage remaining in the lake area and it is known that many important conservation and relocation projects are carried out in order to reduce destructive effects.

One of the most important projects which is rescue of the cultural heritage under the lake of dams in Turkey is the studies which are rescue and conservation studies in Hasankeyf. The mentioned studies were carried out in so far as the Ilisu Dam which is started to be constructed in 2006 by the General Directorate of State Hydraulic Works (DSI) and the planning studies which were started in 1954, which developed the studies due to the soil and water sources of Tigris River in Southeastern Anatolia Region.

In-site conservation and relocation projects carried out to save the cultural heritage in the Hasankeyf settlement, "Science Commission" and Excavation Presidency opinions and Diyarbakir Cultural properties, which were formed by the Principle decision No. 36 taken by the Supreme Council for conservation of cultural heritage on the "Conservation of Immovable Cultural Heritage Affected by the Dam Areas" in line with the decisions of the Conservation Regional Board, the General Directorate of State Hydraulic Works (DSI) and the General Directorate of Cultural Heritage and Museums (KÜVAM) are held in technical and financial cooperation (Sevgi et al., 2017: 17).

Many suggestions have been developed for the salvage application carried out in the historical Hasankeyf settlement, after many years of research, considering the structural situation of each cultural heritage. Among the project methods developed and proposed in the process, according to the conservation status, dimensions, material and construction technique of the immovable cultural properties; In-situ conservation by creating burial environment (fill layers), relocation by separating into unit building elements, relocation by separating into blocks and structural complementary relocation have evaluated as the most feasible methods.

The Conservation and Salvage (Relocation) Projects of the Er Rizk Mosque, which is among the projects of complementary relocation methods which has implemented in the historical Hasankeyf settlement, are the subject of this study. According to this project; the crown gate and the madrasah cells and the mass of portico in the north where uses as a mosque today has relocated by the "Structural Complementary Relocation" method using Self-Propelled Modular Transporters (SPMT). Minaret, which is the section that reached today by conserving its originality and stability in the best way has relocated by the "Relocation by Separating into Unit Building Elements" method and northern facade wall, which is blonging to the original harim has relocated by "Relocation by Separating into 4 Building Blocks" method to an area higher than the highest level of the Tigris River and rebuilt there.

The conservation and salvage (relocation) application of the Er Rizk Mosque in 2019 has constituted as a one of the few important project examples that were applied Relocation by separating into Unit Building Elements, Relocation by Separating into Blocks and Structural Complementary Relocation methods together. The mentioned conservation and salvage (relocation) studies are discussed in detail in this article. 


\section{GíRiş}

Dünya üzerinde çok sınırlı olan tatlı su kaynaklarının korunması, geliştirilmesi ve günümüz toplumun kullanımına sunulması için üretilen çok sayıda proje şekillerinden önemli bir tanesi olan barajlar, suyu biriktirmek amacıyla insan gücü ve tekniğiyle akarsular üzerine yapılan yapay göller olarak tanımlanmaktadır (Akkaya, Gültekin, Dikmen ve Durmuş, 2009: 1-3; Başkaya ve Türk, 2015: 347; Avc1, 1999: 35). Dünya genelinde sayısı her yıl artan barajların inşa edilme nedenleri ülkelere göre değişiklik göstermektedir. Özellikle Türkiye'de Anadolu coğrafyası baraj ve göletlerin yapımına akarsu havzaları ve engebeli bir topografya sayesinde uygun koşullar sunmaktadır.

Türkiye hızlı kalkınma süreci içindeki bir ülke olarak; su kaynaklarının geliştirilmesi yönündeki politikaları ve çalışmaları kapsamında Anadolu coğrafyasındaki akarsu havzalarına 778 baraj inşa etmiş, proje ve inşaat aşamasındaki 727 baraj ile de baraj yatırımlarına hızlı bir şekilde devam etmektedir. Ancak, baraj yatırımları ister istemez kültürel miras alanlarını ve taşınmaz kültür varlıklarını koruma, gelecek nesillere aktarma gibi önemli bir görevle çatışmayı beraberinde getirmektedir (Özdoğan, 2015: 45; Tekeli, 2000: 171). Özellikle ülkemiz gibi tarihte çok sayıda medeniyete ev sahipliği yapmış olan ülkelerde bu çatışma daha da belirgin hale gelmektedir. Tarihteki uygarlıkların çoğu su havzalarında kurulmuştur. Bu nedenle, günümüzde barajlar birçok taşınmaz kültür varlığı kalıntılarını barındıran kültürel miras alanlarını su altında bırakmaktadır (Sönmez, 2012: 213; Bakıroğlu Yılmaz, 2019: 39).

Dünyada ve Türkiye'de, yapılmakta olan baraj göl alanlarında kalan kültürel mirasın kurtarılması veya olumsuz etkilerin azaltılması için çok sayıda yerinde koruma ve taşıma projelerinin yürütüldügü bilinmektedir. Çünkü kültürel miras alanlarında bulunan taşınmaz kültür varlıklarının herhangi bir koruma/kurtarma çalışması yapılmadan baraj göl suları altında korunamayacağı ortaya konmuştur. Nitekim, Dünya Baraj Komitesi (WCD)'nin baraj altında kalan kültürel alanlarında yaptığı çalışmalarda, sürekli yükselip alçalan baraj gölü su seviyesinin yarattığı hareketlerin ve dalga etkisinin çok kısa bir süre içerisinde taşınmaz kültür varlıklarını aşındırarak tahrip ettiği, dip akıntılarının ve özellikle diğer doğal dolgulara göre daha yumuşak olan kültür katmanları dolgularında balıkların yuvalanması sonucu oluşan tahribatlar ortaya konmuştur (WCD, 2001; Özdoğan, 2015: 46; Y1lmaz, vd. 2019: 31).

Ülkemizdeki baraj göl alanlarında kalan kültürel mirasın kurtarılması için yürütülen koruma çalışmalarının en önemlilerinden birini, Hasankeyf tarihi yerleşmesindeki taşınmaz kültür varlıklarının korunması ve kurtarılması için yürütülen çalışmalar oluşturmaktadır. Söz konusu çalışmalar, Hasankeyf tarihi yerleşmesinin Güneydoğu Anadolu Bölgesi’nde Dicle Nehri'nin toprak ve su kaynaklarının geliştirilmesine ilişkin çalışmalar doğrultusunda, 1954 yılında DSİ Genel Müdürlüğü tarafından başlatılan ve 2006 yılında fiilen inşasına başlanan Ilısu Barajı ve Hidroelektrik Santrali Projesinin göl alanında kalacak olması nedeniyle yürütülmektedir (Şekil $1)$.

Hasankeyf tarihi yerleşmesindeki kültürel mirasın kurtarılması için gerçekleştirilen yerinde koruma ve taşıma projeleri, Kültür Varlıklarını Koruma Yüksek Kurulu'nun "Baraj Alanlarından Etkilenen Taşınmaz Kültür Varlıklarının Korunması" hususunda aldığ 36 sayılı İlke Kararı ile oluşturulan "Bilim Komisyonu” ve Kazı Başkanlığı görüşleri ile Diyarbakır Kültür Varlıklarını Koruma Bölge Kurulu'nun kararları doğrultusunda, Devlet Su İşleri Genel Müdürlüğü (DSİ) ve Kültür Varlıkları ve Müzeler Genel Müdürlüğü (KÜVAM) teknik ve mali işbirliğinde yapılmaktadır (Sevgi, vd. 2017: 17). Söz konusu projeler kapsamında Er Rızk Camisi'nin "Bütüncül Taşıma Yöntemleri” uygulandığı Koruma ve Kurtarma (Taşıma) çalışmaları da yer alamaktadır.

Er Rızk Camisi, 2019 yılında gerçekleştirilen başarılı bir koruma çalışması ile yeni Hasankeyf yerleşimde oluşturulan arkeopark alanındaki yeni yerine bütünüyle taşınmış ve taşıma sonrası koruma uygulamaları yapılarak, ılısu baraj projesinin göl suları altında kalma riskinden kurtarılmıştır. Söz konusu yapıda gerçekleştirilen koruma ve kurtarma (taşıma) müdahaleleri, bu çalışmada detaylı olarak ele alınmıştır.

\section{Tarihçe, Mimari Özellikler ve Taşıma Öncesi Durum}

Tarih boyunca önemli bir yerleşim yeri olan Hasankeyf' in Dicle nehri kenarındaki yerleşim alanı "Aşağı Şehir" olarak adlandırılmaktadır. Aşağı şehir yerleşim alanı, günümüze ulaşan Eyyubi dönemine ait önemli taşınmaz kültür varlıklarını barındırmaktadır (Arık, 1993: 35). Er Rızk Camisi adıyla anılan eser de, aşağı şehir yerleşiminde Eyyubi dönemine ait en önemli taşınmaz kültür varlıkları arasında bulunmaktadır. 


\section{sanat}

Er Rızk Cami, Dicle Nehri'nin güney yakası kenarında, tarihi Artuklu köprüsü ile Yukarı Şehir (kale) arasında yer almaktadır (Şekil 2). Avluya geçiş kapısında bulunan kitabeye göre Hasankeyf Eyyubi meliki Ebu'l Mefâhir Süleyman tarafından 811/1409 yılında yaptırılmıştır (Kılc1, 1987: 160; Yurddaş, 2002: 173; Kozbe, 2017: 287). Caminin özgün planında kuzey-güney doğrultusunda uzanan dikdörtgen planlı bir yapı olduğu, üç tarafı revaklı dikdörtgen bir avlunun güneydeki kısa kenarına "Ters T" planlı bir harim bölümünün, kuzeydeki kenarına ise ortada yapıya geşiçi sağlayan taç kapısısın ve taç kapının iki yanında avluya revaklar ile açılan dört mekânın ve kuzeydoğu köşesinde ise bir minaresinin bulunduğu bilinmektedir (Kılc1, 1987: 162; Yurddaş, 2002: 173) (Şekil $3)$.

Er Rızk Camisi çeşitli dönemlerde büyük tahribatlar ve onarımlarla değişiklikler geçirmiştir. Caminin güneyinde yer alan ibadet mekânı heyelan sonucu yıkılmıştır. Günümüze özgünlüğünü ve sağlamlığını koruyarak ulaşan bölümleri minaresi, portali, medrese bölümünün doğu yönündeki mekanları, harim bölümünün kuzey duvarı ve harim mekânlarına ait yıkıntı haldeki duvar kalıntılarıdır. Uzun yıllar harebe halinde kalmış olan cami, 1953 yılında yapılan onarım çalışmaları ve eklemeler sonucunda; avlunun kuzeyindeki medrese hücrelerinin önünde bulunan revak bölümünün çapraz tonozlu üst örtüyü taşıyan beş adet ayak kalacak şekilde bir mihrap duvarının eklenmesi ve enine iki sahanlı cami mekânı oluşturulmasıyla yeniden işlev kazandırılarak, kullanıma açılmıştır (Kılc1, 1987: 162; Kozbe, 2017: 287). Sözkonusu onarımlar ve eklemeler kapsamında taçkapının batısında kalan hücre kuzeye ve batıya doğru genişletilerek caminin kadınlar bölümü oluşturulmuştur (Şekil 4, Resim 1, 2).

Taş süsleme işçiliğinin üst seviyelerde olduğu taç kapı ve minare, caminin anıtsal bölümleridir. Taç kapı üç dilimli ve yüksek kemerli bir niş şeklinde düzenlenmiş olup kavsarası mukarnas dolgularla süslüdür. Mukarnas dolgunun altında üç tarafı dolaşan bir kitabe frizi ve bunun altında birbiri ile kesişen kıvrımlı hatlar arasında Allah'ın doksan dokuz ismi yazılıdır. Kapı açıklığının iki yanında geometrik motiflerle süslü birer yuvarlak madolyon vardır. Kapının iki kenarında ise mukarnas başlıklı sütünce vardır (Kılc1, 1987: 161; Yurddaş, 2002: 173). Caminin kuzeydoğu köşesine bitişik, yüksek kare prizmal kaide üzerindeki silindirik gövdeli minare, dört ana bölüme ayrılmıştır ve her bölüm değişik bezemeye sahiptir. Minarenin dişa fazla çıkıntı yapmayan tek şerefesi ile kısa tutulmuş bir petek kısmı bulunmaktadır. Minarenin şerefesine, gövdesi içerisinden çift sarmallı çıkış merdiven sistemiyle ulaşılmaktadır (Yurddaş, 2002: 173; Uluçam, 2017: 15).

Caminin büyük ölçüde tahrip olan harim bölümünün kısmen ayakta kalabilen kuzey cephe duvarı dışındaki diğer kısımları büyük oranda yıkılmış olup kısmi duvar kalıntıları şeklinde günümüze ulaşmıştır. Kuzey duvarının ön yüzü ileri düzeyde taş işçiliğine ve simetrik bir cephe düzene sahiptir. Ortada üstü istiridye şeklinde biten bir niş ve sağda mukarnaslı bir niş şeklinde iki kapı bulunmakta olup, soldaki kap1 yıkıktır. Duvarın üstünde konsollara oturan çıkıntı vardır (Resim 1,2). Kuzey duvarının arka yüzü çeşitli dönemlerde değişikliklere uğramıştır (Kılc1, 1987: 161; Kozbe, 2017: 287).

Er Rızk Camisi'nin tamamında taş ve bağlayıcı harç malzeme olarak kireç harcı kullanılmış olup; harim, revaklar, medrese bölümleri, taç kapı ve minarede kesme taş malzeme olarak bölgenin yerel ana kayaç grubundan olan sarımsı krem beyaz renkli, ince taneli ve gözenekli yerel kireç taşları kullanılmıştır. Caminin günümüze ulaşan bazı duvarlarının örgü tekniği düzgün kesme taş işçiliğinden farklı olarak aynı duvar üzerinde moloz, kaba yonu ve daha küçük boyutlarda kesme taş örgülü bölümler olmak üzere değişiklik teknikler görülmektedir. Bu farklılığın, camide oluşan tahribatlara bağlı olarak, gerçekleştirilen çok sayıdaki onarım müdahalelerden kaynaklandığı anlaşılmaktadır. Moloz taş örgülü bölümlerde kullanılan kireç bağlayıcı harçlar iri taneli kum, taş tozu agregalıdır. Kesme taş örgüler arasındaki yumuşak geçişi sağlamak için kullanılan bağlayıcı harçlar ince taneli yapıda ve gri-krem renklidir (Eskici ve Şener, 2018: 9). Caminin medrese hücrelerinin pişmiş toprak-seramik künk örgülü kubbelerinin üzerinde ve harimin avluya bakan kuze y cephesi üst kenarını kuşatan saçak konsolları arasında kalan ve niş görünümündeki yüzeylerde özgün olduğu düşünülen sıva uygulamaları görülmektedir.

Er Rızk Camisi'nde, 2010 yılında mevcut durumunun stabil hale getirilmesine yönelik olarak yapılan koruma uygulamalarıyla, acil yapısal sorunlarının büyük oranda giderildiği anlaşılmaktadır (Ebru Gültekin, 2010: 4; Eskici ve Şener, 2018: 12). Sözkonusu bu uygulamalarda; çelik strüktür ile harim kuzey cephe duvarının ve taç kapının desteklenmesi, derz dolgu uygulamaları, örgü içlerindeki boşlukların, yarık ve çatlakların sıvı harç enjeksiyonu yapılarak sağlamlaştırılması, eksik örgü bölümlerinin benzer taş malzeme ile tamamlanması ve duvar üstü "capping” uygulamalarıyla korunması gibi uygulamaların taşıma öncesi yapılan incelemelerde etkin olduğu görülmüştür.

Er Rizk Camisi'nin koruma ve kurtarma (taşıma) uygulamaları öncesinde projesinde ve yerinde yapılan incelemede, uğradığ birçok tahribatın yapılan son onarımlardaki güçlendirme ve sağlamlaştırma çalışmaları ile büyük oranda giderildiği görülmüştür (Eskici ve Şener, 2018: 12). Bu nedenle, kapsamlı güçlendirme ve 


\section{sanat}

sağlamlaştırma uygulamalardan daha çok lokal/kısmi koruma uygulamalarının yapılmasına ihtiya ç duyulduğu görülmüş ve bu yönde çalışmalar gerçekleştirilmiştir. Ancak koruma ve kurtarma (taşıma) uygulamaları öncesinde niteliksiz eklerin kaldırılması gerekli görülmüştür.

\section{Koruma ve Kurtarma (Taşıma) Uygulamaları}

Dünyada, baraj göl alanlarında kalmış kültürel miras alanlarındaki taşınmaz kültür varlıklarının kurtarılması için yürütülen projelerde, çağdaş koruma ilkelerinin belirlendiği uluslararası tüzük ve yönetmeliklerde yer alan hükümlerde belirtildiği gibi, ilk olarak özgün konumunda korunmasını esas alan uygulamaların değerlendirildiği çalışmalar bulunmaktadır. Ancak taşınmaz kültür varlığının yerinde koruma yöntemleri uygulanarak özgün konumunda korunması imkânsız hale gelmesi durumunda en son seçenek olarak "Taşıyarak Koruma Yöntemleri"nin uygulandığı görülmektedir. Taşıyarak koruma yöntemlerinin, taşınmaz kültür varlığını özgün konumundan ve sahip olduğu kültürel değere katkıda bulunan çevresel etkenlerden ayırmak sonucunu ortaya koyması nedeniyle taşınmaz kültür varlığının özgünlüğünü zedeleyen bir eylem olduğu unutulmamalıdır (Curtis, 1979: 9).

“Taşıyarak Koruma Yöntemleri”, yok olma riski altındaki bir taşınmaz kültür varlığının özgün konumundan çeşitli taşıma yöntemleri kullanılarak önceden belirlenen uygun bir konuma nakledilmesi olarak tanımlanmaktadır. Baraj gölü suları altında kalma riski altındaki taşınmaz kültür varlıkları için uygulanan “Taşıyarak Koruma Yöntemleri” projenin etki türüne ve taşınmaz kültür varlıklarının korunma durumuna, yapım tekniğine, mimari özeliklerine ve önemine göre değişiklikler gösterdiği görülmektedir (Ahunbay, 1998: 325; Y1lmaz, 2019: 152).

Ilısu Barajı ve Hidroelektrik Santrali Projesi'nin göl alanında kalacak olan tarihi Hasankeyf yerleşimindeki taşınmaz kültür varlıklarının korunması ve kurtarılması için yürütülen çalışmalar, dünyada uygulanan örnekleri arasında, büyük kapsamlı ve önemli kurtarma çalışmalarından biri olarak yerini almıştır. Yürütülen kurtarma çalışmalarında uygulanması için birçok proje yöntemi önerisi getirilmiştir. Önerilen proje yöntemleri arasından taşınmaz kültür varlıklarının korunma durumuna, boyutlarına, malzemesi ve yapım tekniğine göre; Gömü ortamı (dolgu katmanları) oluşturularak yerinde koruma, birim yapı elemanlarına ayırarak taşıma, bloklara ayırarak taşıma ve strüktürel bütüncül taşıma yöntemleri en uygulanabilir yöntem türleri olarak değerlendirilmiş ve uygulanmasına karar verilmiştir (Sevgi vd., 2017: 13; Uluçam, 2017: 17).

Tarihi Hasankeyf yerleşiminde bütüncül taşıma yöntemlerinin uygulandığı projeler içerisinde yer alan ve çalışmamızın konusunu oluşturan Er Rızk Camisi'nin 2019 yılında gerçekleştirilen koruma ve kurtarma (taşıma) çalışmaları, birim yapı elemanlarına ayırarak taşıma, bloklara ayırarak taşıma ve strüktürel bütüncül taşıma yöntemlerinin birlikte uygulandığıaz sayıdaki önemli proje örneklerinden birini oluşturmuştur.

Er Rızk Camisi'nin koruma ve kurtarma (taşıma) için hazırlık çalışmaları kapsamında, öncelikle mevcut durumlarının belgelenmesi için filmleri ve fotoğrafları çekilmiş, detaylı fotogrametrik haritaları, çizimleri, ölçümleri ve modelleri yapılmıştır. Bu belgelemeler kurtarma (taşıma) uygulamaları için ihtiyaç duyulan çeşitli proje çizimlerinin oluşturulmasında ve taşıma yöntemlerinin uygulama aşamalarının belirlenm esinde çok yoğun bir şekilde kullanılmıştır.

Er Rızk Camisi'nin koruma ve kurtarma (taşıma) çalışmaları için hazırlanan projelerde, taç kapının ve medrese hücrelerinin yer aldığı ve günümüzde cami olarak kullanılan kuzeydeki revaklı mekân kütlesi kendinden tahrikli modüler lastik tekerlekli taşıyıcıların (SPMT) kullanıldığı "Strüktürel Bütüncül Taşıma" yöntemiyle, özgünlügünü ve sağlamlığını koruyarak günümüze ulaşan bölüm olan minare "Birim Yap1 Elemanlarına Ayırarak Taşıma" yöntemiyle ve özgün harime ait kuzey cephe duvarı ise "Bloklara Ayırılarak Taşınma" yöntemi ile 4 yapı bloğuna ayrılarak taşınması; Ilısu barajın tamamlanması ile birlikte Dicle Nehri'nin sularının yükselebileceği en yüksek seviyeden daha yüksek bir kottaki alana nakledilmesi ve burada yeniden kurulumlarının gerçekleştirilmesi ön görülmüştür (Şekil 5, 6, 7). Ayrıca projede hazırlık kapsamında, bütün mekân kütlelerinin iç ve dış çevrelerinde yapılacak arkelojik kazı çalışmasıyla temellerinin ortaya çıarılması ve temizlik sonrası ortaya çıkması olası mezarların taşınması ön görülmüştür.

Er Rızk Camisi'ndeki uygulamalarda öncelikle niteliksiz eklentiler olan, ikinci avlunun doğu ve güney doğu kesimindeki wc-abdest mekânı, avlu duvarları, giriş holü, günümüzde ibadet mekânı olarak kullanılan ana yap1 kütlesinin güneyine ve batısına eklenen mekân eklentileri özgün mekân kütlelerine zarar verilmeksizin, itinayla 
ayıklanarak temizlenmiştir (Resim 4). Bu çalışma ardından caminin çevresinde ve iç mekânlarında 2-3,5 m arasında değişen derinliklerde arkelojik kazı çalışması yapılarak yapı temelleri ortaya çıkarılmış (Resim 3). ortaya çıkartılan yapı temel duvarlarında koruma-onarım, destekleme-güçlendirme müdahaleleri gerçekleştirilmiştir. Bu kapsamda; yatay / düşey örgüde ve birim eleman düzey indeki bölgesel kayıplar, mevcut örgü ile uyumlu malzeme ve harç kullanılarak sağlamlaştırılmış, eksik örgüler tamamlanmış; gevşek ve muhdes derz harçları temizlenmiş, derz boşalmaları derinliğe göre değişen teknikte harç karışımlarıyla doldurularak derz onarımı yapılmıştır.

Yapı temellerinin ortaya çıkarılması ve sağlamlaştırma veonarımların tamamlanmasından sonra, caminin harim mekanına ait özgün kuzey cephe duvarının 4 yapı bloğuna ayırılarak taşınması şeklinde hazırlanmış proje kapsamındaki imalat uygulamalarına geçilmiştir. Öncelikle kuzey cephe duvarının ağırlığı, boyutu ve taşıma güvenliği gözetilerek, 4 yapı bloğa ayıracak dikey kesim hatları duvar yüzeylerindeki süsleme, yazıt v.b. gibi özellikli unsurları ile taşıyıcı elemanların kritik bölümlerine denk gelmeyecek şekilde belirlenmiştir. Duvarın temel seviyesinde betonarme 1zgara kiriş sisteminin imalatı için duvarın temel seviyesinde betonarme kirişin sığabileceği ebatta boşluklar açılmıştır. Betonarme 1zgara kiriș sistemi, harim duvarının bağım sız bölümler halinde taşınmasına olanak sağlayacak şekilde, projesinde boyutlarına ve ağırlığına göre hesaplanarak belirlenmiş olan $80 \mathrm{~cm}$ yüksekliğinde ve $30 \mathrm{~cm}$ genişliğindeki krişlerden 4 bölüm halinde imal edilmiştir. SPMT (kendinden tahrikli modüler taşıyıcı) platformla taşıma ve mobil vinç ile kaldırma esnasında harim kuzey duvarının stabilitesinin sağlanabilmesi için duvarı ön ve arka cepheden destekleyecek çelik strüktür sistemi imal edilmiştir. Çelik destek sisteminin imalatı, duvarda belirlenmiş olan kesim hatlarına ve betonarme 1zgara kiriş sistemindeki 4 bölüme uygun olarak gerçekleştirilmiştir. Çelik destek sisteminin ön ve arka cephedeki bölümleri arasındaki bağlantı, üsten çelik bağlantı profileri ile sağlanmıştır. Bu aşamada eşzamanlı olarak, betonarme ızgara kiriş sistemine, harim duvarının mobil vinç ile kaldırılmasını mümkün kılacak; çelik halat, ankraj demiri v.b. bağlantı elemanlarının imalat ve montajı yapılmıştır. Son çalışma olarak harim kuzey duvarı, kablo ve disk kesim makineleri kullanılarak belirlenmiş olan kesim hatlarından kesilmiş, ilişsili olduğu duvardan ayrılması gerçekleştirilerek duvar blokları kaldırma ve taşımaya hazır hale getirilmiştir (Resim 5; Şekil 7).

Er Rızk Caminin, harime ait toplamda 720 ton ağırlığa sahip özgün kuzey cephe duvarı 4 yapı bloğuna ayrılmış, duvar yapı blokları önce 650 ton kaldırma kapasiteli mobil vinç kullanılarak mevcut yerinden kaldırılmıș ve geçici olarak caminin avlusunda oluşturulan stok alanına alınmıştır. Daha sonra yapı blokları, (montaj sırası geldiğinde final /nihai pozisyonuna yerleştirilmek üzere )12 akslı bir SPMT (kendinden tahrikli modüler taşı11 1) platform üzerine alınarak $4670 \mathrm{~m}$ mesafede ve 48 metre daha yüksekte olan yeni konumuna taşınmışlardır (Resim 6).

Cami harim kuzey cephe duvarının, 4 yapı bloğuna ayırılarak taşınması çalışmaları ile eş zamanlı olarak başlanmış olan minare bölümündeki çalışmalar, "Birim Yapı Elemanlarına Ayırarak Taşıması" kararı doğrultusunda birim yapı elemanlarının numaralanarak sökülmesi, taşınması ve arkeopark alanında belirlenmiş olan yerde yeniden kurulması gibi projesinde belirtilmiş imalatları kapsamaktadır. Minarenin taşınmasında; ilk önce minareyi oluşturan birim yapı elemanlarının mevcut durumunu ayrıntılı gösteren tespit ve belgeleme çizimleri üzerinde numaralandırılma sistemi oluşturulmuştur. Bu sistemde minarede bulunan 169 adet örgü sırası alttan üste doğru 7 grup (A,B,C,D,E,F,G) oluşturacak şekilde bölümlere ayrılmıştır. A grubu 38, B grubu 17, C grubu 27, D grubu 26, E grubu 31, F grubu 18 ve G grubu 12 sıra taştan oluşmuştur. Gruplardaki her bir örgü sırasındaki kesme, iç ve dış cephe üzerindeki yerine göre farklı harf ve sayı kodu ile numaralandırılmıştır. Ayrıca kesme taşlar üzerinde, birim yapı elemanlarının birbirleriyle ilişkisini belirleyen düşey aks çizgileri oluşturularak yeniden kurulumda kullanılacak referans hatları belirlenmiştir (Şekil 6).

Minarede yapı elemanlarının söküm çalışmasına en üsteki G12 kodlu örgü sırasından başlanmıştır. Her bir örgü sırasının sökümü öncesi kesme taş birim yapı elemanlarının yüzey temizliği, iç ve dış örgü arasındaki dolgu malzeme temizliği, birim yapı elemanlarına zarar vermeden yapılmıştır. Bu işlemden sonra dış ve iç örgüdeki birim yapı elemanları düşey aks çizgisi dikkate alınarak numaralandırma işlemi yapılmış ve sökümü yapılacak örgü sırası kodunun üzerine yazıldığı ahşap tablaların üzerine konulan, örgü sıranın kodu ve birim yap1 elemanlarının numarasının yer aldığı birebir şablon oluşturulmuştur. Sökümde örgüdeki her bir birim yap1 eleman geleneksel el aletleri (murç, keski v.b.) kullanılarak yerlerinden çıkartılımış, taşıyıcı tabla üzerinde şablondaki kodları ile eşleştirerek ahşap tablalara yerleştirilmişlerdir. Uygulamada her örgü sırası söküm öncesi ve sonrası çizimsel ve fotografik yöntemler ile belgelenmiş, her 10 örgü sırasındabir olmak üzere bağlayıcı harç örnekleri alınarak, sonradan analizleri gerçekleştirilmiştir (Resim 7). 
Sökümü tamamlanan örgü sırasının dizildiği taşıma tablaları, ağırlığa ve tablaların fiziksel özelliklerine uygun türde vinç kullanılarak kaldırılmış, taşıyıcı platformların üzerine alınarak önceden belirlenmiş olan depo alanı na taşınmıştır. Her bir tabla stok alanında tek sıra olarak yerleştirilmiştir (Resim 8). Sökümü yapılan birim yapı elemanlarının depo alanına taşınmasının ve burada bekletilmesinin nedeni, minarenin yeni yerinde yeniden kurulum çalışmalarının ancak en son sökümü gerçekleştirilen en alt örgü sırasından sonra başlanacak olmasıdır.

Er Rızk Camisi minare bölümünün söküm ve taşıma çalışmalarını takiben yeni Hasankeyf'te bulunan arkeopark alanındaki yeni yerinde önceden hazırlanmış temel kaidesi üzerine en son sökülen en alt örgü sırasından başlayarak ve numaralama sisteminde kullanılan kodlama düzeni takip edilerek aslına uygun şekilde yeniden kurulum başlanmıştır. Minarenin yeniden kurulumunda özgün işçilik ve yapım tekniğine bağlı kalınmış; bağlayıcı harç olarak benzer harç malzemesi kullanılmıştır. Kullanılan harç için, özgün harç örneklerinin analiz sonuçlarında belirlenen oranlara riayet edilmiştir. Minarenin yeniden kurulum çalışmaları ilk sökümü ve taşınması gerçekleştirilen en üsteki örgü sırasını oluşturan birim yapı elemanlarının yerine yerleştirilmesi ile tamamlanacaktır. Minarenin birim yapı elemanlarının sökümü, taşınması ve yeniden kurulması çalışmalarının planlama ve projelendirme aşamasında \% 30'luk özgün bir birin yapı elemanı kaybı oluşabileceğ i öngörülmüş ancak söküm ve taşıma çalışmalarında bu oranın çok altında bir oran olan \% 2 birim yapı elemanı kaybı gerçekleşmiştir. Çünkü minarede birim malzemelerinin bağlantısında metal kenetlerin çok az sayıda şerefe bölümünde kullanılmasına karşın yapının gövde, kaide ve temelindeki örgüde rastlanmamıştır. Taş ve harç ile inşa edilmiş olan minarede söküm esnasında bu nedenle özgün malzeme zaiyatı kendi yapısal ve fiziksel sorunları olan çok az birim malzemede görülmüştür. Buna bağlı olarak da daha az yeni malzeme ve işçiliktebirim yapı elemanları kullanılarak yeniden kurulum çalışmalarının tamamlanması öngörülmektedir.

Hasankeyf'te baraj göl suları altında kalmaktan, strüktürel bir bütün halinde taşınarak kurtarılan taşınmaz kültür varlıklarının en sonuncusu Er Rızk Camisinde özgün taç kapı ve medrese hücrelerinin yer aldığı ve günümüzde cami olarak kullanılan kuzeydeki revaklı mekân kütlesi olmuştur. Bu revaklı mekân kütlesinde uygulanan "Strüktürel Bütüncül Taşıma Yöntemi”, cami’nin mevcut yerindeki zemin koşullarında sahip olduğu statik koşulları ve strüktür bütünlügünü koruyarak, aynı zamanda da yapı yükünün dengeli dağılımını sağlayan bir betonarme platforma eklenmiş kriko sistemiyle kaldırılıp kendinden tahrikli modüler lastik tekerlekli taşıyıcıların (SPMT) üzerine alınarak taşınması şeklinde planlanmıştır (Şekil 5). Söz konusu betonarme kaldırma/taşıma plağ 1 ile birlikte kaldırma ağırlığ yaklaşık 1700 tona ulaşmış olan revaklı mekân kütlesinin, strüktürel bütüncül taşıma çalışmalarının ilk aşaması kapsamında betonarme kaldırma/taşıma plağı altında yer alan $30 \mathrm{~cm}$ kalınlığında betonarme temel zemini (kaldırma temeli) oluşturulmuştur (Resim 9). Takip eden aşamada revaklı mekân kütlesinin kaldırma/taşıma plağının geleceği özgün duvar hattında eşit aralıklarla, 36 adet, $50 \mathrm{~cm}$ çapında altlı üstlü ve birbiri ile kesişen delikler açılmıştır. Bu deliklerin içerisine, $\varnothing 32 \mathrm{~mm}$ 'lik inşaat çeliğinden hazırlanan donatı yerleştirilmiş ve hızlı priz alan yüksek dayanımlı rötresiz beton ile boşluk bırakmayacak şekilde doldurulmuştur. Daha sonra revaklı mekân kütlesinin kaldırılmasını ve taşınmasını sağlayacak olan $100 \mathrm{~cm}$ kalınlığındaki betonarme taşıma plağının imalatı gerçekleştirilmiştir (Resim 9). Betonarme kaldırma/taşıma plağı, altında yer alan betonarme kaldırma temelinden mesnet alan hidrolik krikolar sayesinde, yukarı yönde uygulanan kaldırma kuvvetini, duvarlara yerleştirilen betonarme kaldırma kirişleri vasıtasıyla mekân kütlelerinin strüktür sistemine (duvarlarına) ileten ana taşıyıcı sistem elemanıdır. Betonarme kaldırma/taşıma plağının bir diğer görevi ise revaklı mekân kütlesinin ağırlığının kendinden tahrikli modüler lastik tekerlekli taşıyıcıların (SPMT) üzerinde yayılı yük olarak dağıtılmasını sağlamaktır (Sevgi vd., 2017). Kaldırma/Taşıma plağının imalatında sonra revaklı mekân kütlesinin, bu plağa yerleştirilmiş olan her biri 22 cm çapında ve 6 m uzunluğunda ( 3 m'lik 2 adedin eklenmesiyle) olan 55 adet çelik boru sütunu ve her bir sütuna monte edilmiş 50 ton kapasiteli hidrolik krikolar vasıtasıyla 1,5 m'lik 3 seferde toplam 4,5 m yüksekliğe kaldırılması gerçekleştirilmiştir (Resim 10). Revaklı mekân kütlesi, zemin kotunun taşıma yolunun zemin kotundan $3 \mathrm{~m}$ aşağıda olması nedeniyle, alanın kültürel katmanları gözönüne alınarak bu katmanlara zarar verilmemesi amacıyla ilk olarak $3 \mathrm{~m}$. yükseliğe kaldırılarak mevcut yol kotuna uyumlu planlanan taşıma yolu kotuna çıkartılmıştır. Bu kaldırma ile revaklı mekân kütlesi altında oluşan 3 m'lik boşluk, 30 m uzunluğunda, $15 \mathrm{~m}$ genişliğinde ve $1.5 \mathrm{~m}$ yüksekliğinde iki adet betonarme platformun üst üste dökülmesiyle giderilerek, SPMT'nin taşıma yolu kotundan mekân kütlesinin altına sürülmesine imkan verecek hale getirilmiştir. Revaklı mekân kütlesi son olarak taşıma yolu kotu seviyesinden 1,5 m daha yüksekliğe yüksekliğe kaldırılmasıyla özgün zemin kotundan 4,5 m yüksekliğe kaldırılmış olup, altına (SPMT) sürülerek üzerine alınma (yüklenmesi) aşamasına hazır hale getirilmiştir (Resim 11). 
Er Rızk Camisi'nin revaklı mekân kütlesinin altına 22 akslı 3 sıra (toplam 66 aks) kendinden tahrikli modüler lastik tekerlekli taşıyıcı (SPMT) sürülerek yerleştirilmiştir. Daha sonra (SPMT) platformların üzerine yüklenen revaklı mekân kütlesi, taşıma hareketi için özel olarak maksimum \%2 eğimde, 15 m genişliğinde ve yaklaşık $4670 \mathrm{~m}$ uzunluğunda imalatı yapılan taşıma yolu kullanılarak yaklaşık 48 metre daha yüksekte olan yeni konumuna nakledilerek yerleştirilmiştir (Resim 12). Revaklı mekân kütlesinin kald ırma, taşıma ve yeni konumunda montaj aşamalarında, sistemin son derece küçük ivmelere maruz bırakılmasıyla, mevcut konumundaki statik koşullar neredeyse hiç değişmeden strüktürel bir bütün halinde taşınması mümkün olmuştur.

Er Rızk Camisi’nin "Bütüncül Taşınma Yöntemleri” uygulandığı "Koruma ve Kurtarma Taşıma Çalışmaları" ile baraj göl sahasından çıkarılan özgün mekân kütlelerinin yeni konumunda yeniden kurulumu, restorasyonu ve sergileme çalışmaları gerçekleştirilmektedir (Resim 13). Ayrıca Er rızk Camisi'nin yeni yerinde başta avluyu bat1, kuzey ve doğu yönden sarmalayan revakları, güneydeki özgün harim ile kuzey batı köşedeki hücre mekanları olmak üzere halihazırda eksik olan bölümleri, restitüsyon verileri esas alınarak, geleneksel malzeme ve yığma yapım tekniği uygulanarak cami olarak hizmete açılmasıyla birlikte koruma ve kurtarma (taşıma) uygulamaları başarılı bir şekilde tamamlanacaktır (Resim 14).

\section{SONUC}

Tarihi Hasankeyf yerleşiminde yer alan Er Rızk Camisi, Ilısu baraj projesi göl suları altında kalmaktan kurtarılarak gelecek kuşaklara aktarılabilmesine ve sergilenmesine olanak sağlanabilmesi amacıyla, 2018 - 2019 yılları arasında, Bütüncül Taşınma Yöntemlerinin uygulandığı başarılı bir koruma ve kurtarma (taşıma) çalışmasıyla, yeni Hasankeyf yerleşimde oluşturulan arkeopark alanındaki yeni yerine nakledilmiştir. Er Rızk Cami'nin tarihi, estetik ve mimari değerleri, korunma durumu ve yapım tekniği kadar taşındığı mesafe ve taşınan alanın özellikleri bakımından kültürel mirasın korunmasına yönelik dünyada gerçekleştirilen bu tür çalışmalar arasında bilimsel ve teknik açıdan önemli bir uygulama niteliği taşımaktadır. Er Rızk Camisi'nin Koruma ve Kurtarma (Taşıma) çalışmaları, uzun yıllar süren ulusal ve uluslararası profesyonellerin, bilim insanlarının, ilgili kurum uzmanlarının (DSİ Genel Müdürlüğü ve Kültür Varlıkları ve Müzeler Genel Müdürlüğü) araştırmaları sonucunda cami özelinde yapısal durumu göz önüne alınarak tasarlanmıştır. Projenin interdisipliner uzman ekiplerle ve hazırlanan yönetim planı çerçevesinde bütünleşik koruma ilkelerine dayanılarak yürütülmesi, inancımız odur ki ileriki süreçlerde yok olma tehdidi ile karşılaşan kültürel mirasın korunması/kurtarılması için yürütülecek çalışmalar için önemli birörnek oluşturacaktır.

\section{TEŞEKÜR}

Yazarlar, Devlet Su İşleri Genel Müdürlüğüne, Kültür Varlıkları ve Müzeler Genel Müdürlüğüne, Diyarbakır Kültür Varlıklarını Koruma Bölge Kuruluna, Bilim Komisyonu üyelerine, Hasankeyf Kazı Başkanlığına, Batman Müze Müdürlüğüne, katkı vermiş bütün bilim insanlarına, ana /alt yüklenicilik yapmış bütün firmalara, katkısı olan bütün teknik personel ve işçilere teşekkürlerini sunarlar. 
KAYNAKLAR

Ahunbay, Z. (1998). Hasankeyf'in Korunmas1/ Anıtların Taşınmasıyla İlgili Sorunlar, Gap Bölgesi’nde Kültür Varlıklarının Korunması, Yaşatılması ve Tanıtılması Sempozyumu Bildirileri, 01-05 Haziran 1998, Şanlıurfa, ss. 325- 335.

Arık, M. O. (1993). Kültürümüzün Temel Taşı Hasankeyf Kurtarılmalı, Sanat Dergisi, Sayı (2), 17- 41.

Akkaya, U., Gültekin, A. B., Dikmen, Ç. B., Durmuş, G. (2009). Baraj ve Hidroelektrik Santrallerin (Hes) Çevresel Etkilerinin Analizi: Ilısu Barajı Örneği, 5. Uluslararası İleri Teknolojiler Sempozyumu, 13-15 Mayıs 2009, Karabük. ss. 1- 7.

Akyol, A.A. (2019). Batman, Hasankeyf El Rızk Cami Minaresi Malzeme Analizi Raporu. (Yayınlanmamış Rapor), ER-BU İnşaat Tic. Aş., Devlet Su İşleri Genel Müdürlüğü ve Kültür Varlıkları ve Müzeler Genel Müdürlüğü arşivi, Ankara.

Avcı, İ. (1999). Barajlar, Çevre ve Ilısu Barajı. Mimarlık Dergisi, Sayı (290), 35-38.

Başkaya, Z. ve Türk, E. (2015). Barajların Olası Çevresel ve Sosyo-Ekonomik Etkilerinin Halkın Bakış Açısıyla Değerlendirilmesi: Ilısu Barajı ve Hasankeyf Örneği. Uluslararası Sosyal Araştırmalar Dergisi, Sayı (40), 347-383.

Bakıroğlu Yılmaz, A. (2019). Türkiye’de Baraj Tehdidi Altındaki Arkeolojik Sit Alanlarının Yerinde Korunma Yöntemleri. Yayınlanmamış Yüksek Lisans Tezi, Dokuzeylül Üniversitesi Sosyal Bilimler Enstitüsü, İzmir.

Curtıs, J.O. (1979). Moving Historic Buildings. U.S. Department of the Interior Heritage Conservation and Recreation Service Technical Preservation Services Division, Washington, D.C.

Ebru Gültekin, A. (2010). Hasankeyf İlçesindeki Taşınmaz Kültür Varlıklarının 3. Etap Belgelenmesi İşi; Er-Rızk Camii Malzeme ve Sorunlar Raporu. (Yayınlanmamış Rapor), Sayka İnşaat Mimarlık Mühendislik Ltd. Şti., Devlet Su İşleri Genel Müdürlüğü ve Kültür Varlıkları ve Müzeler Genel Müdürlüğü arşivi, Ankara.

Eskici, B. ve Şener, Y.S. (2018). Hasankeyf Er Rızk Camisinin Taşınması, Yerinde Kalacak Mimari Elemanların Korunması ve Yeni Yerine Taşınan Mimari Kütlede Yapılması Gerekli Koruma Müdahalelerine Yönelik Malzeme Koruma Raporu. (Yayınlanmamış Rapor), Nuran Demirtaş Proje Mimarlık Ltd., Devlet Su İşleri Genel Müdürlüğü ve Kültür Varlıkları ve Müzeler Genel Müdürlügü arşivi, Ankara.

Kozbe, G. (2017). Batman İli Kültür Envanteri (III..Cilt). Batman : Batman Valiliği İl Kültür ve Turizm Müdürlüğü.

Kılı1, A. (1987). "Hasankeyf Vakıf Eserleri”, V. Vakıf Haftası, Restorasyon ve Vakıfların Ekonomik ve Sosyal Etkileri Semineri, 7-13 Aralık 1987, 159-187, Ankara.

Özdoğan, M. (2015). Barajlar ve Arkeoloji. İstanbul Teknik Üniversitesi Vakfi Dergisi, Say1 (70), 43-48.

Sevgi, S., Murat, Ç., Yılmaz, M. (2017). Hasankeyf Zeynel Bey Türbesi'nin Koruma ve Kurtarma (Taşıma) Projesi, Kâgir Yapılarda Koruma ve Onarım Semineri IX Bildirileri, 05-06 Aralık 2017, İstanbul. ss. 10- 37.

Sönmez, M.E. (2012). Barajların Mekân Üzerindeki Olumsuz Etkileri ve Türkiye’den Örnekler. Gaziantep Üniversitesi Sosyal Bilimler Dergisi, Say1 11(1), 213 -231.

Uluçam, A. (2017). Hasankeyf’teki Kültürel Mirasın Bugünkü Durumu, XX. Uluslararası Ortaçağ ve Türk Dönemi Kazılar ve Sanat Tarihi Araştırmaları Sempozyumu Bildirileri, 02-05 Kasım 2016, Sakarya. ss. 14- 36.

Tekeli, İ. (2000). Büyük Projelerin Geliştirilmesinde ve Uygulanmasında Tarih Boyutu. Zeugma Yalnız Değil, Türkiye'de Barajlar ve Kültürel Miras. Tarih Vakf1 Yayınları, İstanbul. ss.170-172.

WCD, (2001). Heritage at Risk 2001-2002: Dams and Cultural Heritage. Erişim: https://www.icomos.org/risk/2001/dams2001.htm\# (18.01.2019).

Yılmaz, M. (2019). Yok Olma Riski Altindaki Taşinmaz Kültür Varliklarinin Korunma Yöntemleri. Yayınlanmamış Yüksek Lisans Tezi, Gazi Üniversitesi Güzel Sanatlar Enstitüsü, Ankara.

Yılmaz, M., Eskici, B., Eliüşük, M., Akgönül, S., Şener, Y.S. (2019). Hasankeyf Mardinike Külliyesi Kalıntılarının Sağlamlaştırılması ve Su Altında Korunmasına Yönelik Uygulama Çalışmaları. MASROP E-Dergi, 13 (1), 30-51.

Yurttaş, H. (2002). Hasankeyf'de Artuklu, Eyyûbî, Akkoyunlu ve Osmanlı Dönemi Mimari Eserleri. Türkler C.8, Yeni Türkiye Yayınları, Ankara, ss.100-101. 


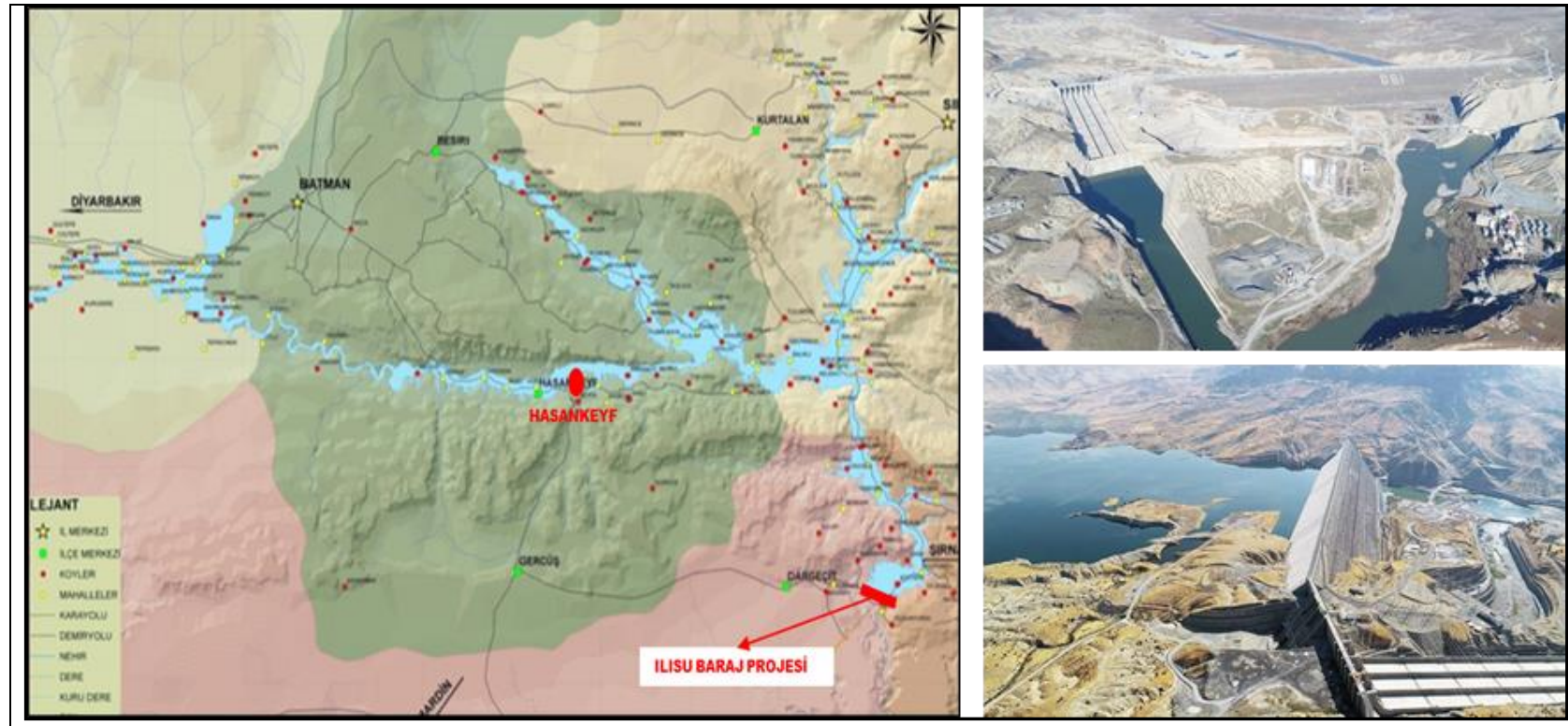

Şekil 1. Ilısu Barajı ve Rezervuar Alanı (Devlet Su İşleri Genel Müdürlüğü arşivi).

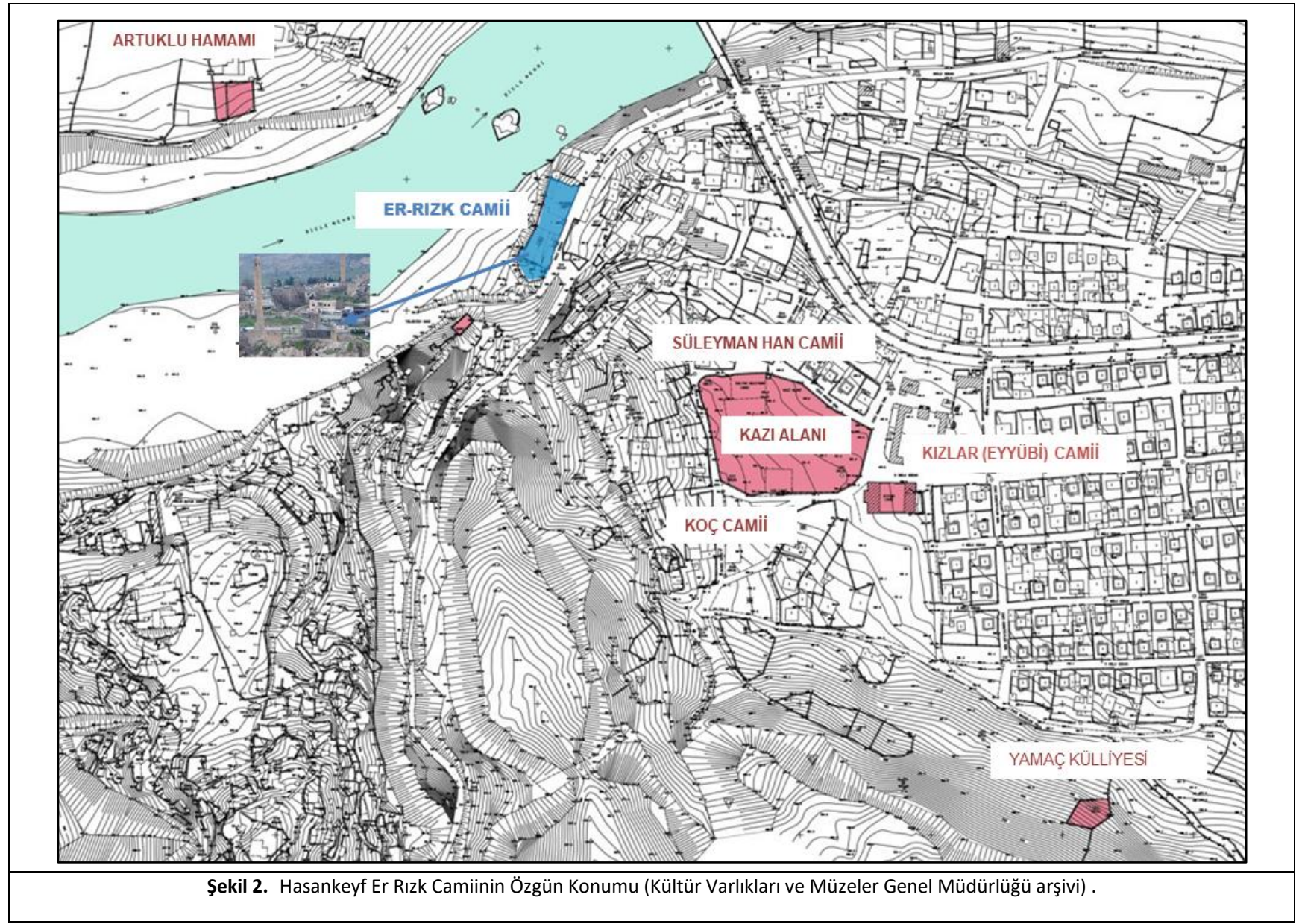




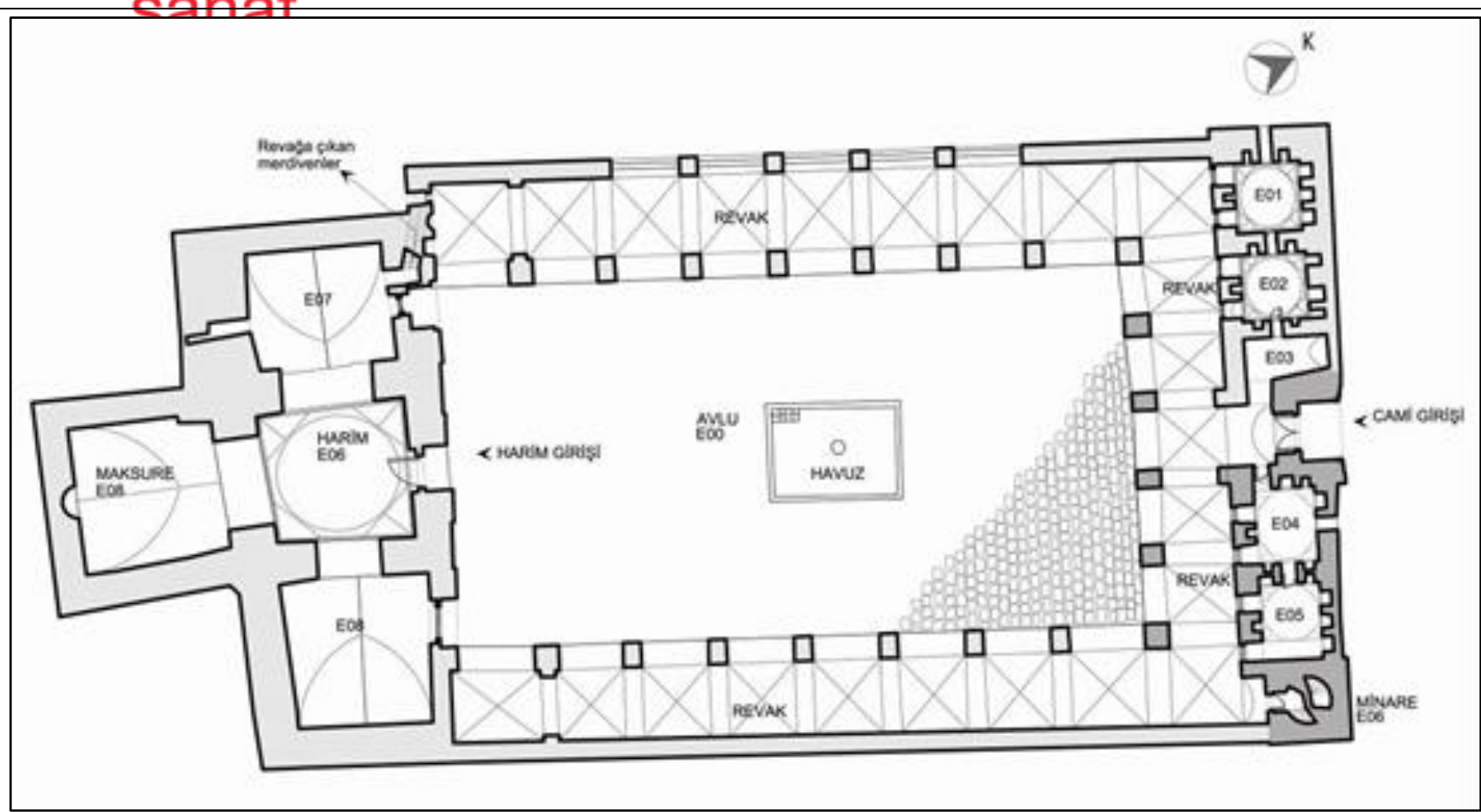

Şekil 3. Hasankeyf Er Rızk Camiinin Özgün Restitüsyon Planı (Devlet Su İşleri Genel Müdürlüğü ve Kültür Varlıkları ve Müzeler Genel Müdürlüğü arşivi).

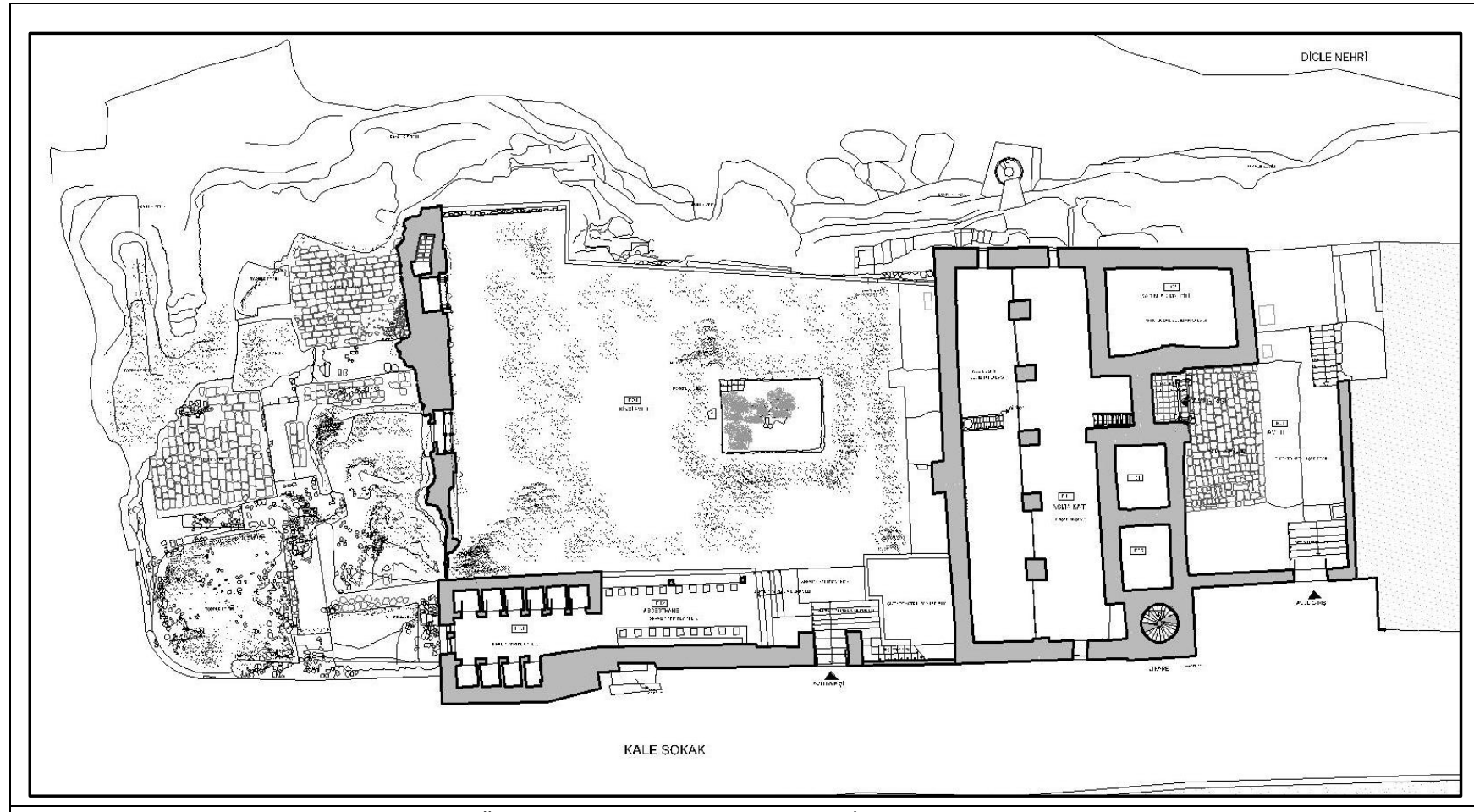

Ş̧ekil 4. Hasankeyf Er Rızk Camiinin Taşıma Öncesi Mevcut Durum Planı (Devlet Su İşleri Genel Müdürlüğü ve Kültür Varlıkları ve Müzeler Genel Müdürlüğü arşivi). 


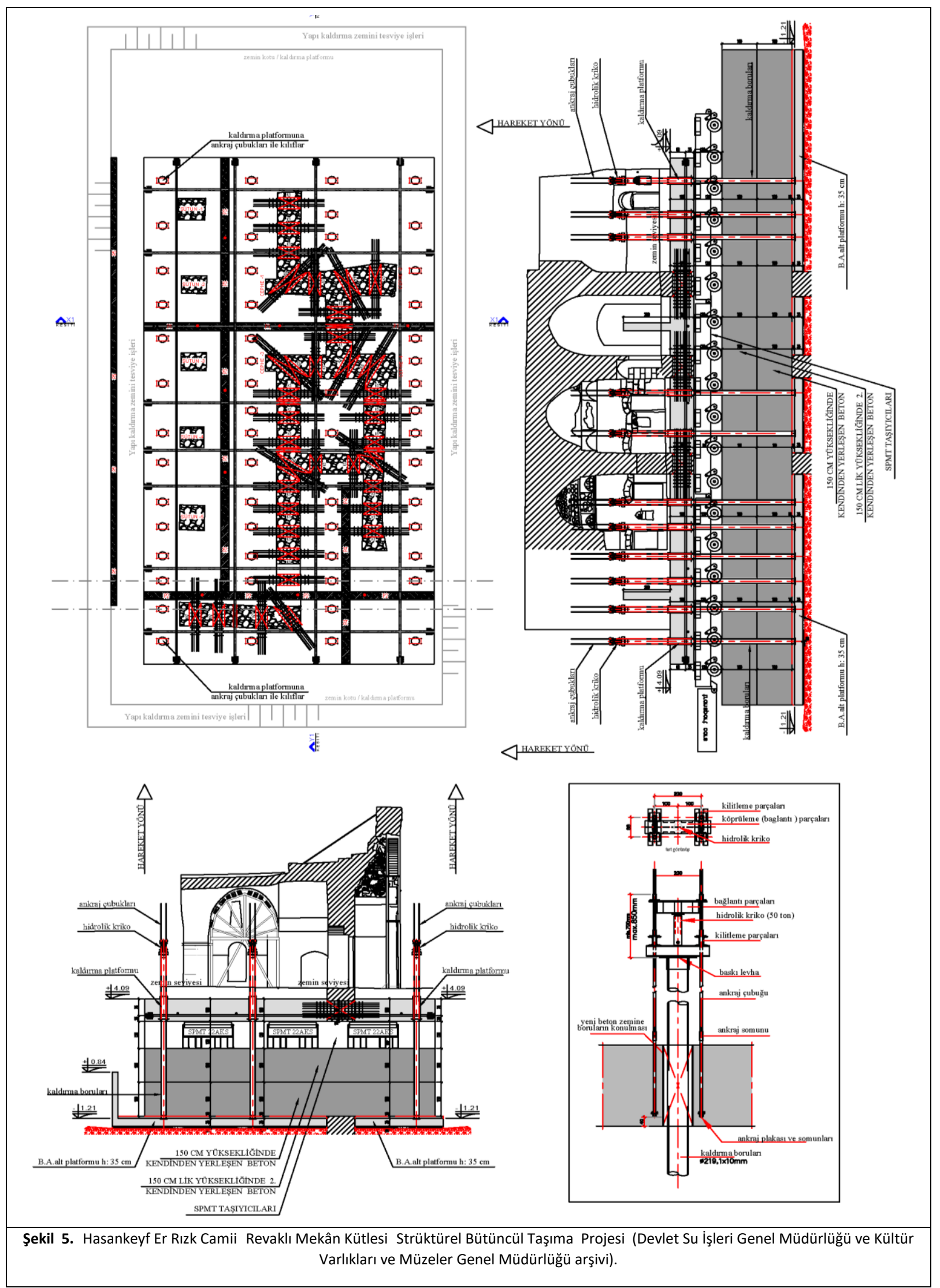




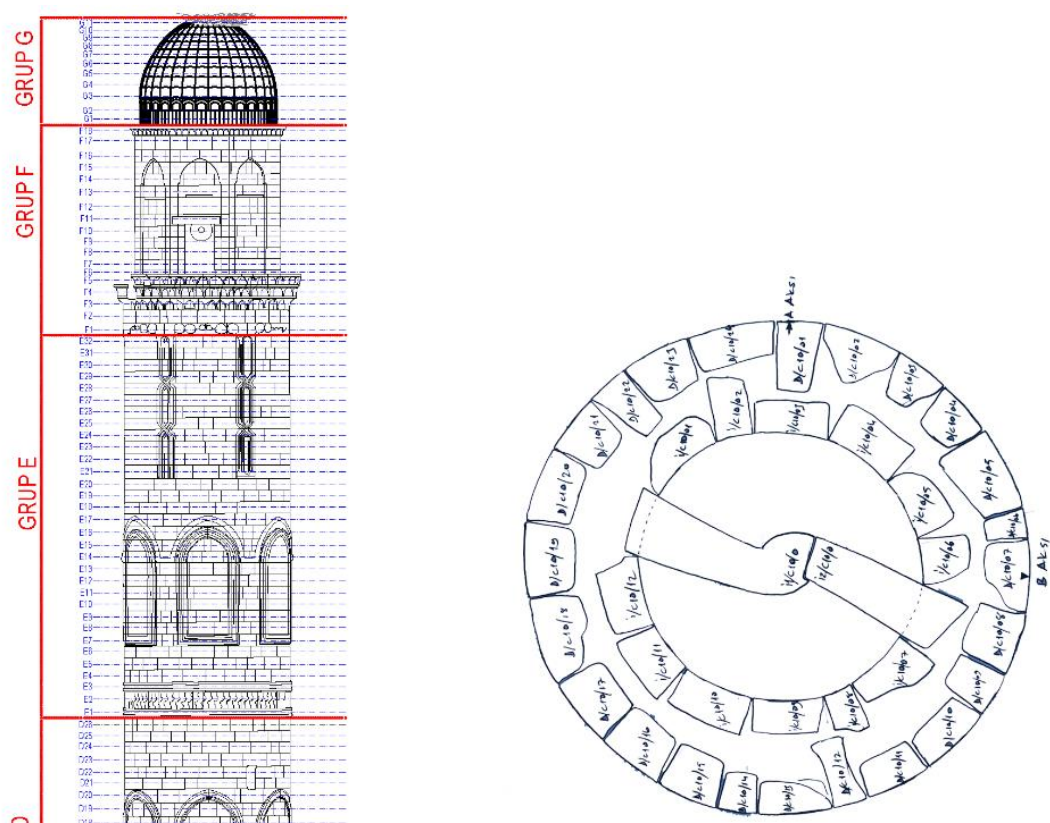

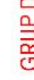

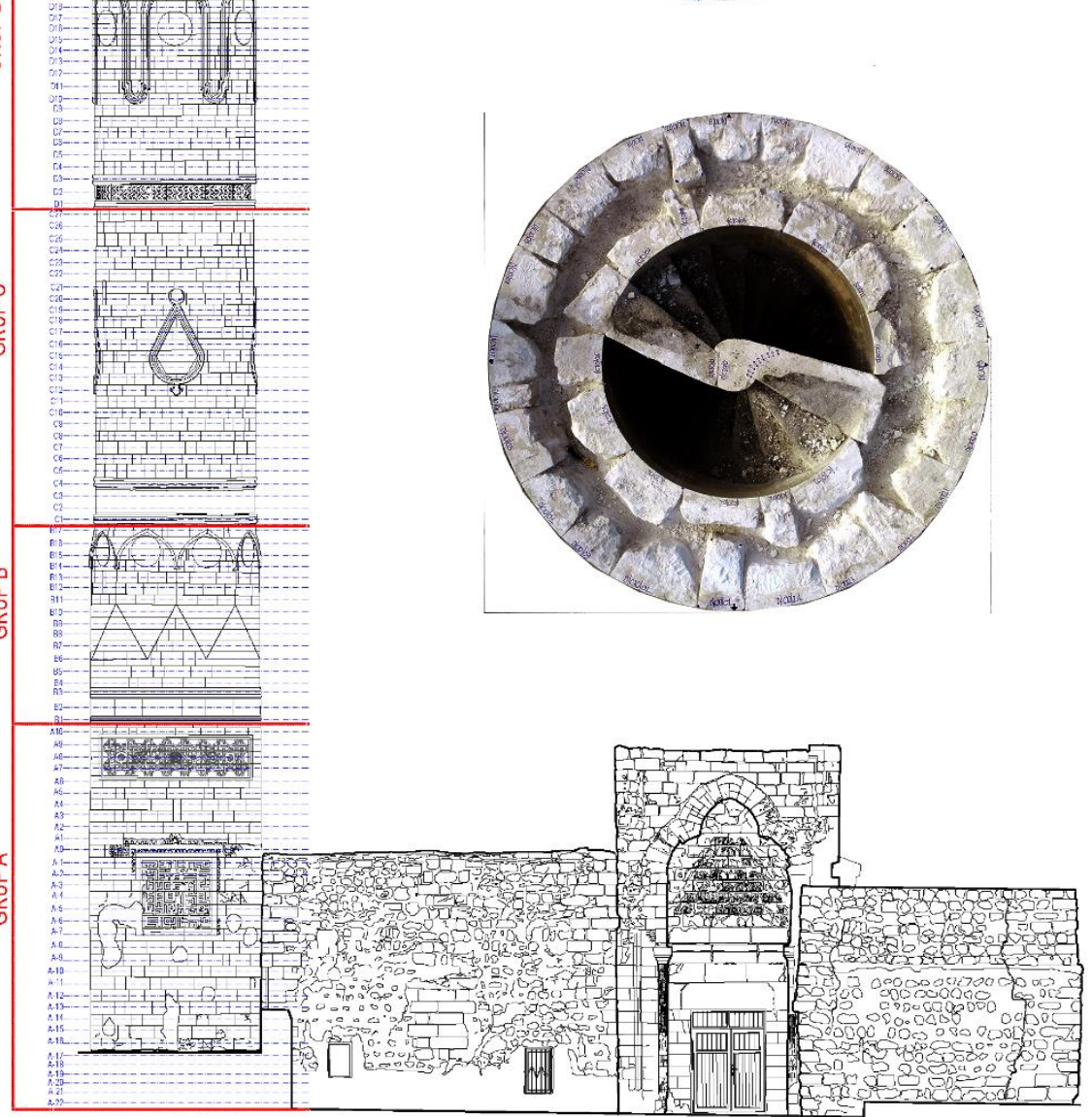

Şekil 6. Hasankeyf Er Rızk Camii Minaresi Örgü Sıraları Ve Birim Yapı Elemanlarının Numaralandırma Sistemi (Devlet Su Işleri Genel Müdürlüğü ve Kültür Varlıkları ve Müzeler Genel Müdürlüğü arşivi) 

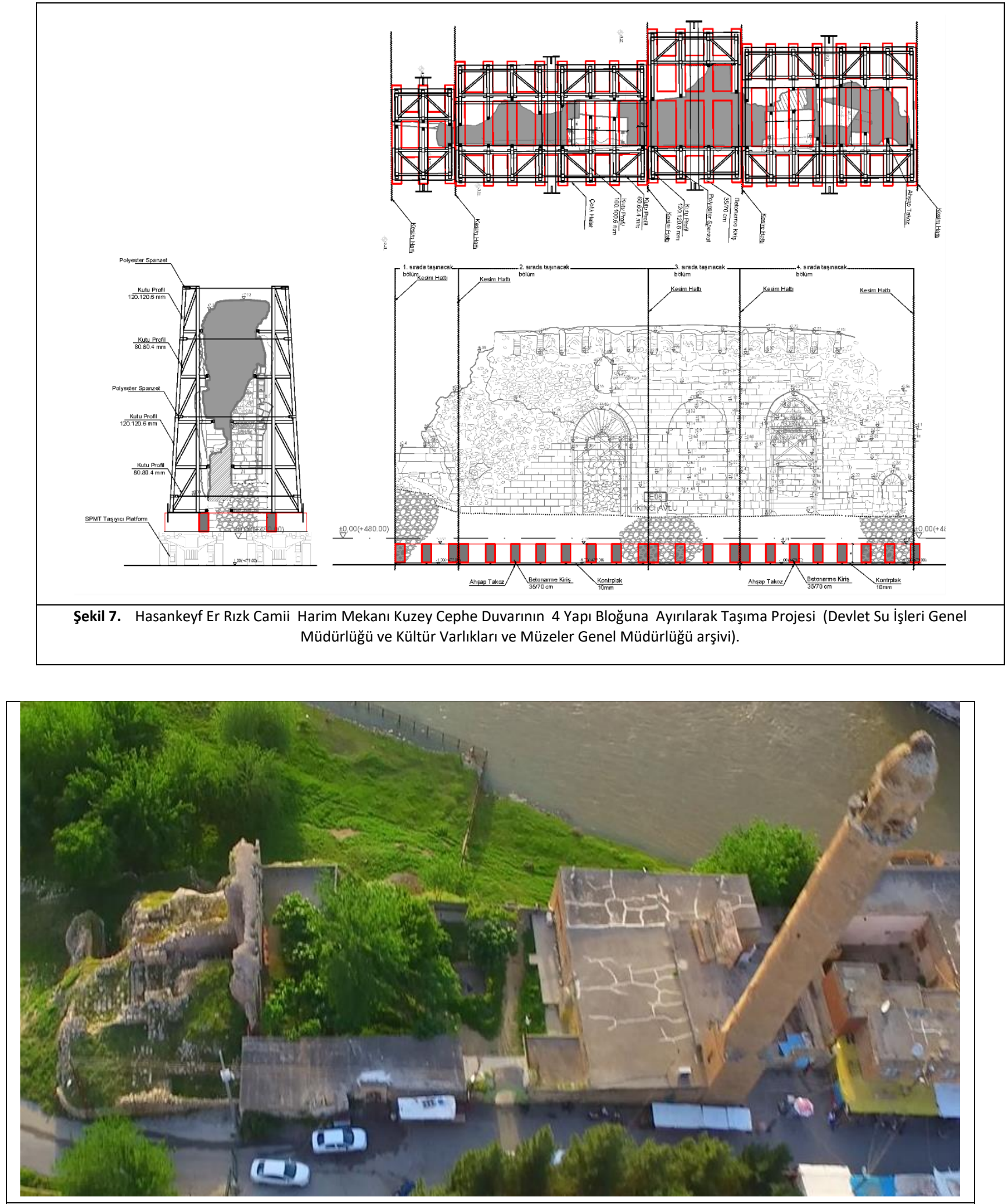

Resim 1. Hasankeyf Er Rızk Camiinin Taşıma Öncesi Mevcut Durumu (Batıdan'dan). 


\section{akademik sanat}
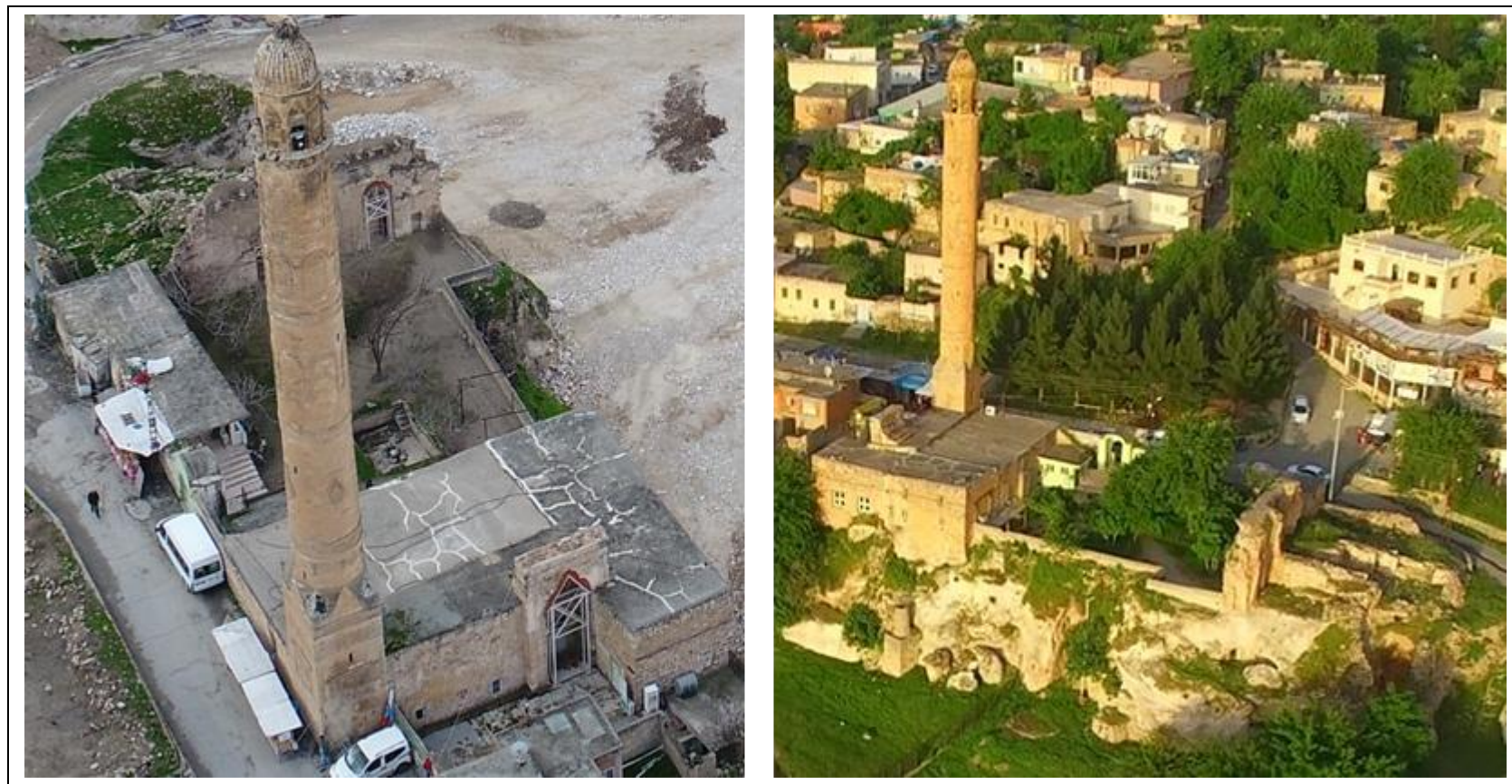

Resim 2. Hasankeyf Er Rızk Camiinin Taşıma Öncesi Mevcut Durumu (kuzeydoğu’dan ve Güneybatı’dan).
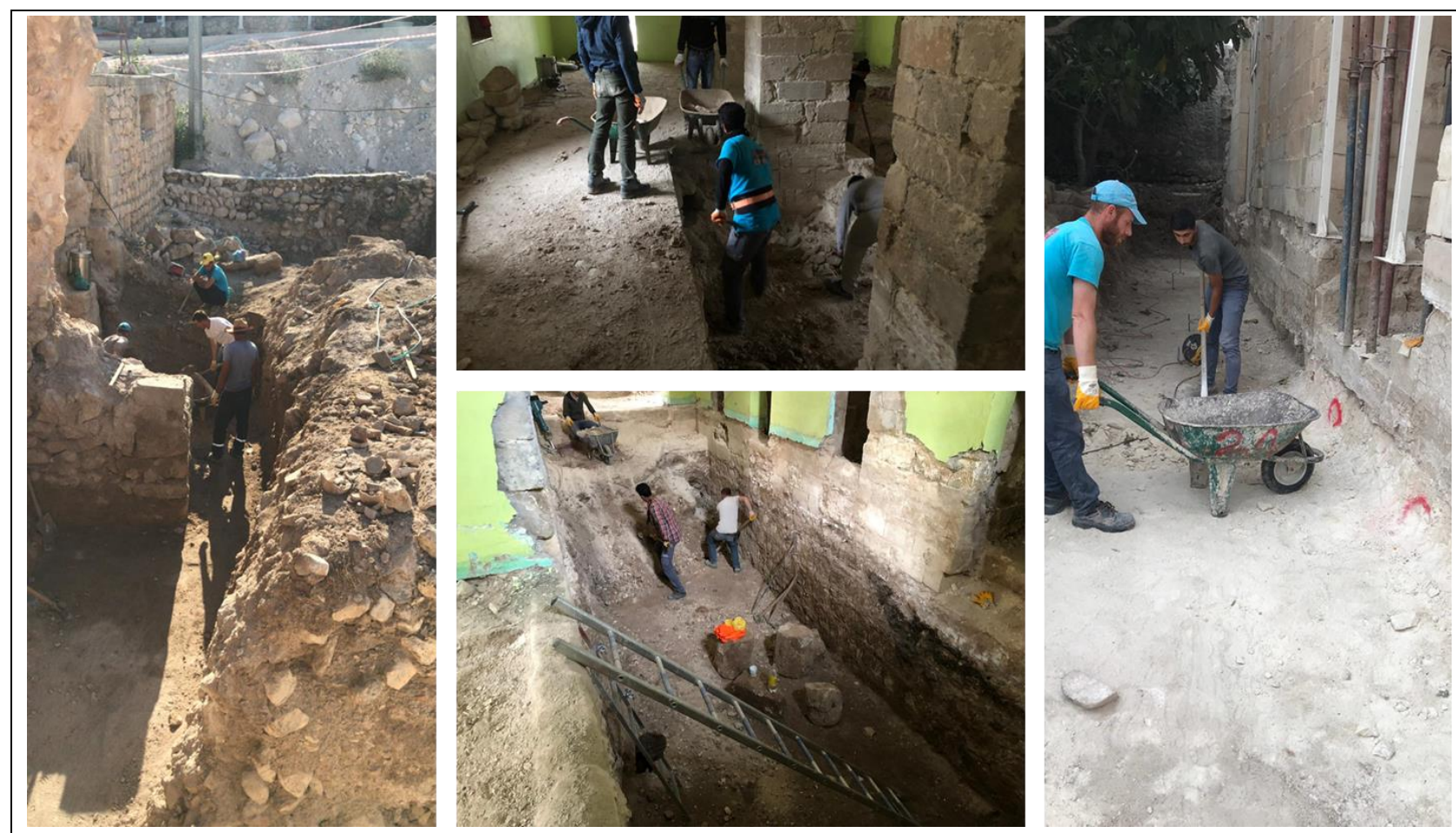

Resim 3. Hasankeyf Er Rızk Camiinin Temellerinin Arkelojik Kazı Çalışmasıyla Ortaya Çıkarılması (ER-BU İnşaat Tic. Aş. arşivi). 


\section{akademik}
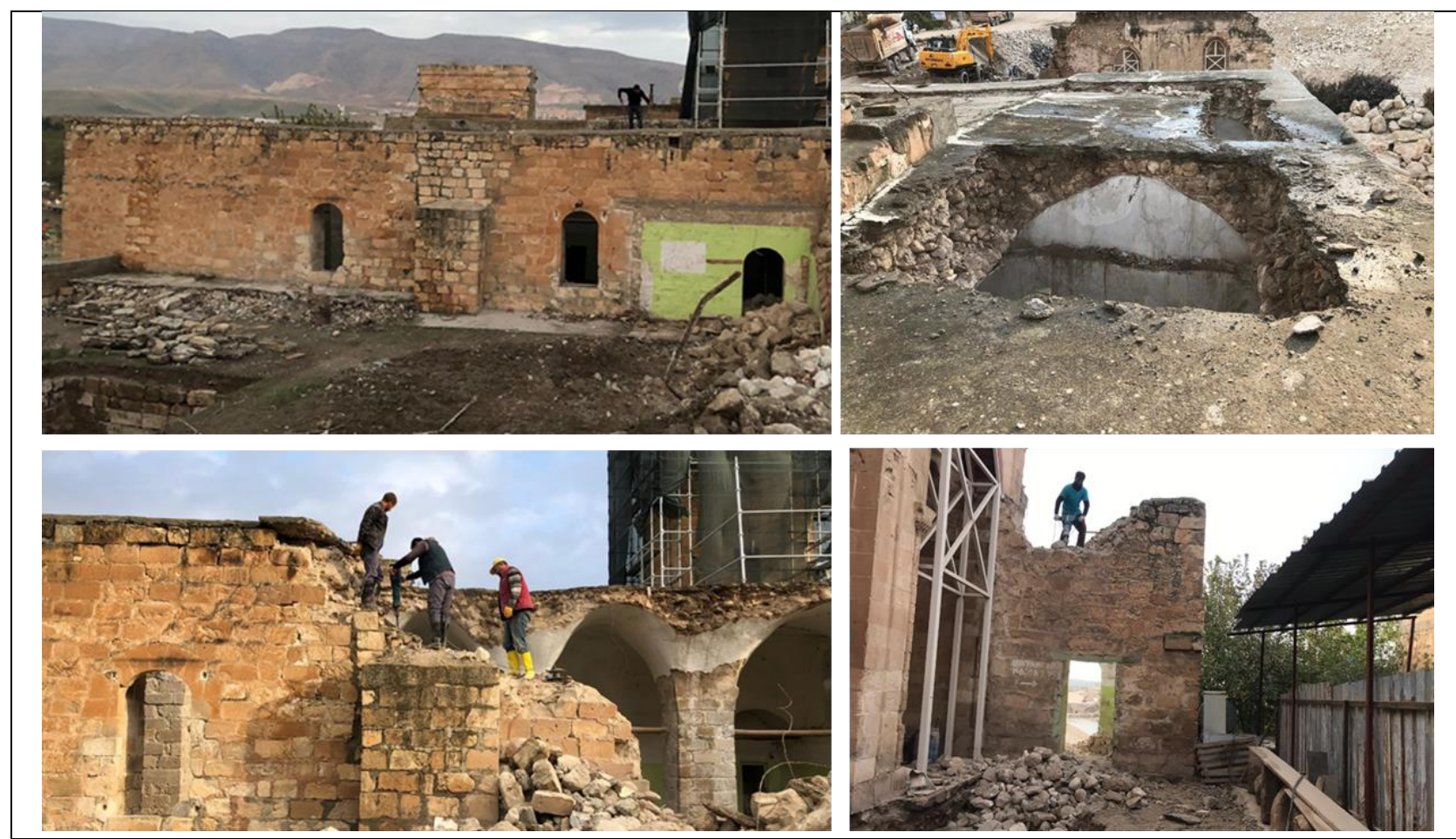

Resim 4. Hasankeyf Er Rızk Camiinin Taşıma Öncesi Niteliksiz Eklerin Kaldııılması Çalışmaları (ER-BU İnşaat Tic. Aş. arşivi) . 

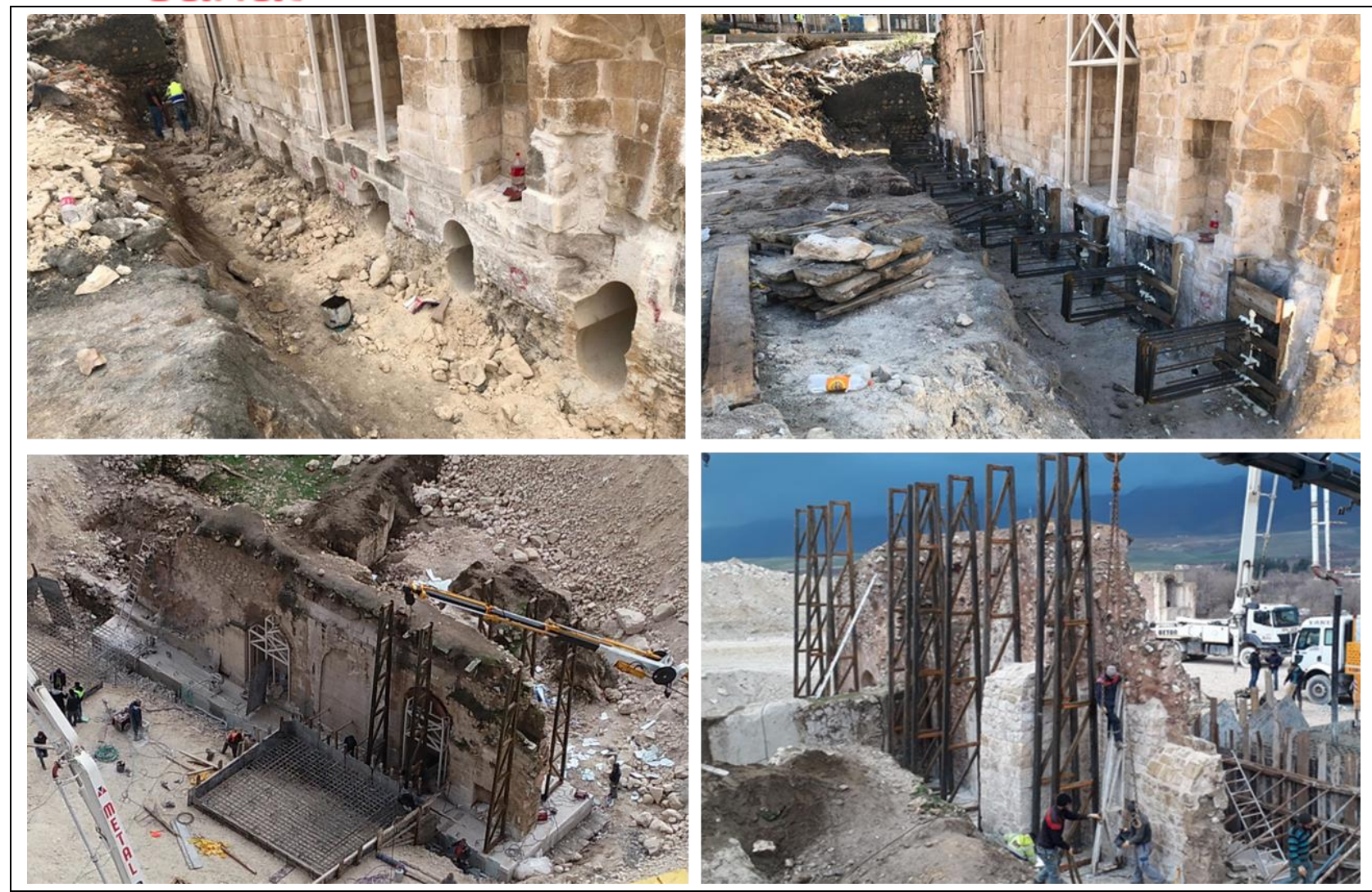

Resim 5. Hasankeyf Er Rızk Camii Harim Mekanı Kuzey Cephe Duvarının 4 Yapı Bloğuna Ayırılarak Taşıma çalışmaları .

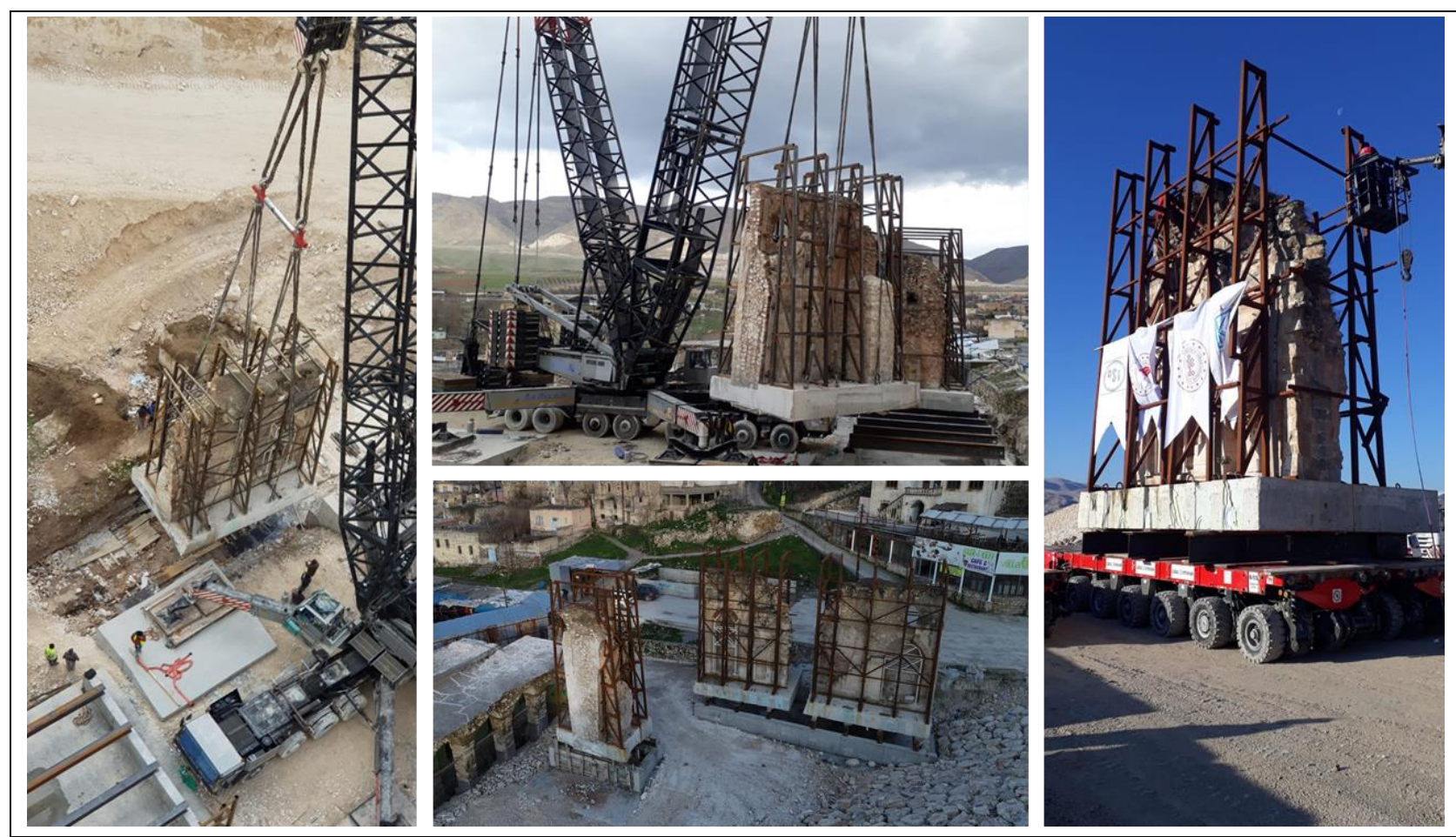

Resim 6. Hasankeyf Er Rızk Camii Harim Mekanı Kuzey Cephe Duvarının 4 Yapı Bloğuna Ayrılarak 650 Ton Kaldırma Kapasiteli Mobil Vinçle Yerlerinden Kaldırılma ve Taşıma Çalışmaları (ER-BU İnşaat Tic. Aş. arşivi). 


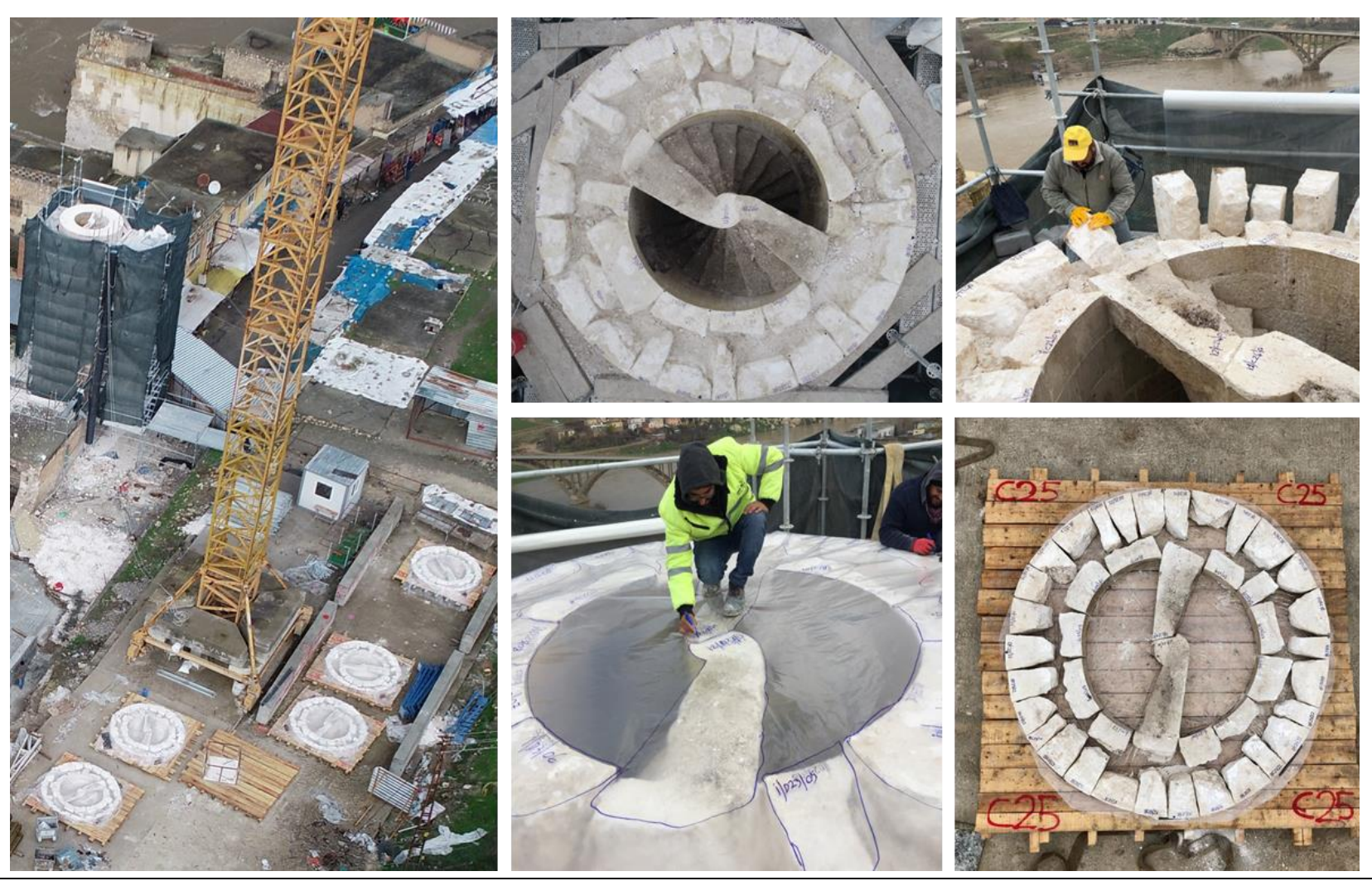

Resim 7. Hasankeyf Er Rızk Camii Minaresinin Birim Yapı Elemanlarının Numaralandırma ve Söküm Çalışmaları .
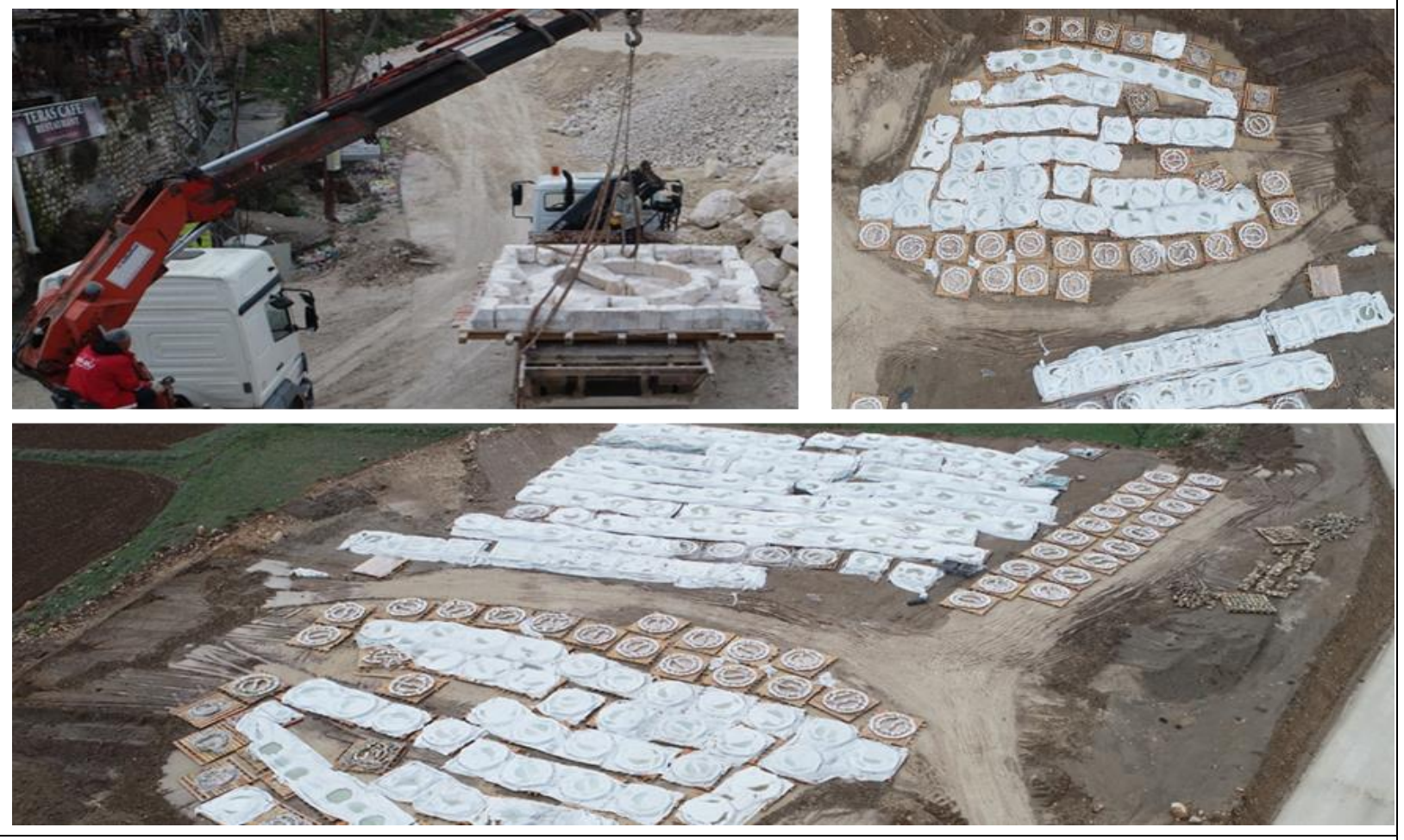

Resim 8. Hasankeyf Er Rızk Camii Minaresinin Minaresinin Sökümü Yapılan Birim Yapı Elemanlarının Taşıyıcı Platformların Üzerine Alınarak Depo Alanına Taşınması. 


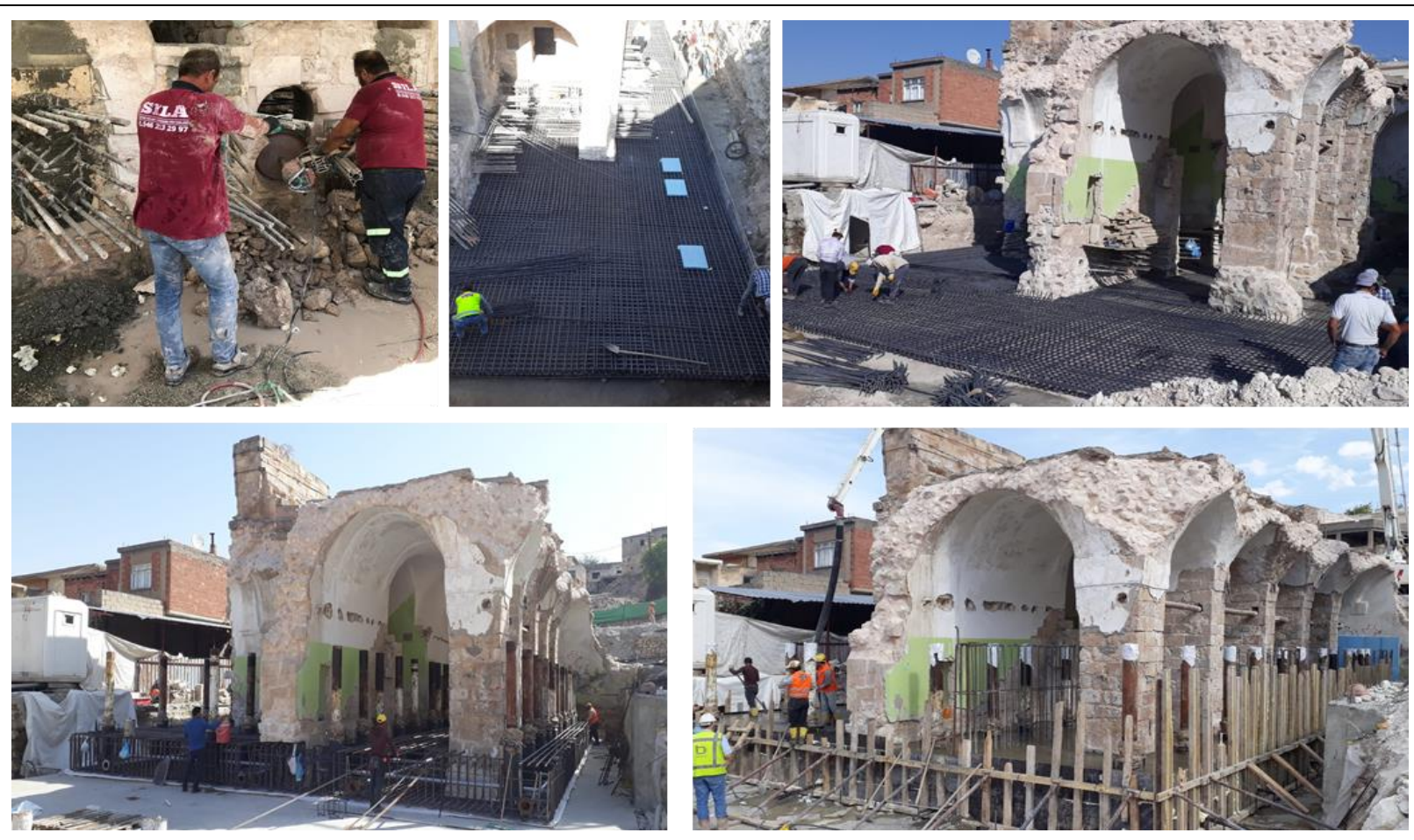

Resim 9. Hasankeyf Er Rızk Camii Revaklı Mekân Kütlesi Strüktürel Bütüncül Taşıma Projesi Betonarme Temel Zemini Platformu ve 


\section{akademik sanat}

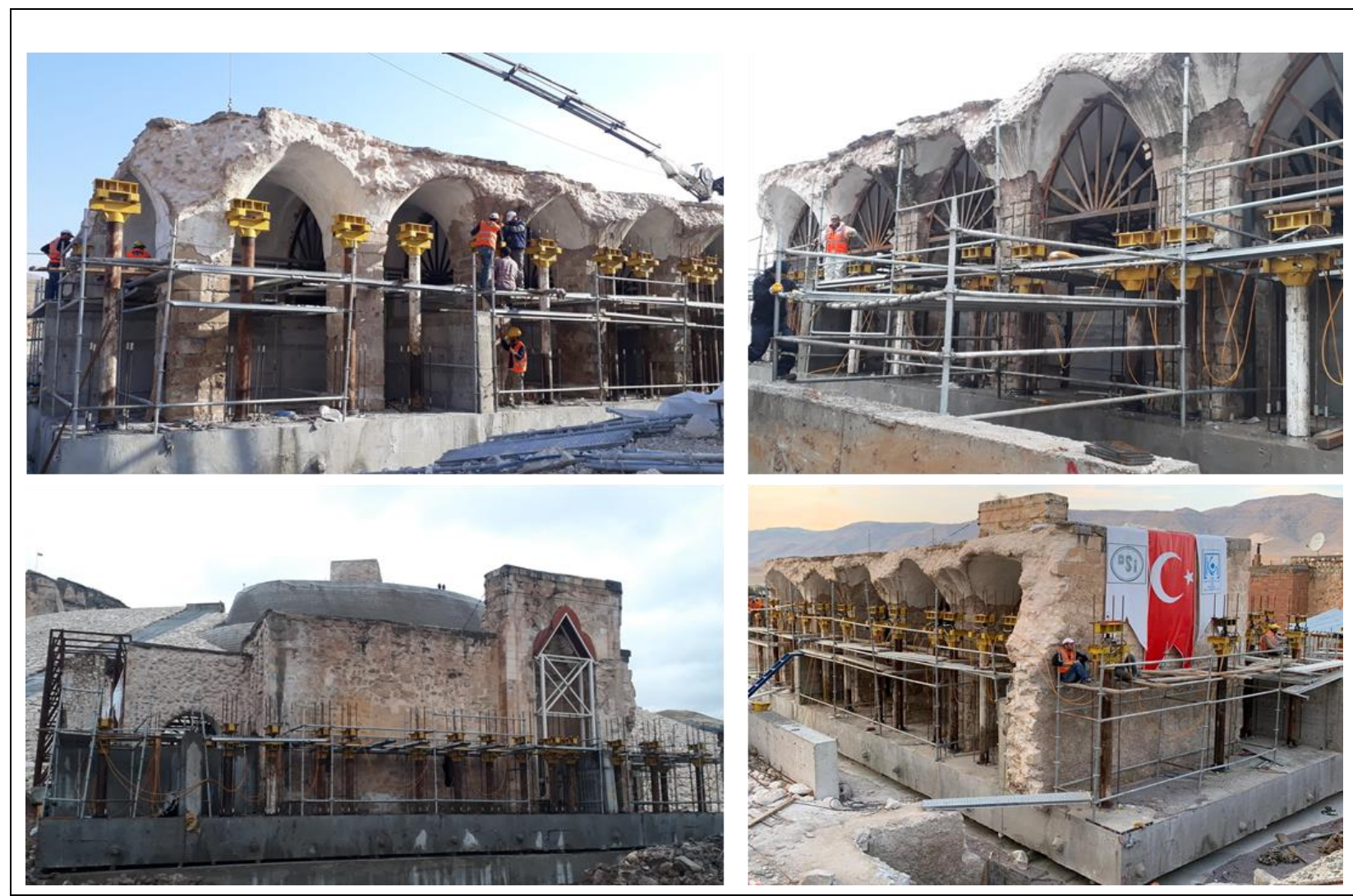

Resim 10. Hasankeyf Er Rızk Camii Revaklı Mekân Kütlesi Strüktürel Bütüncül Taşıma Projesi Kaldırma Kriko Sisteminin Kurulması.
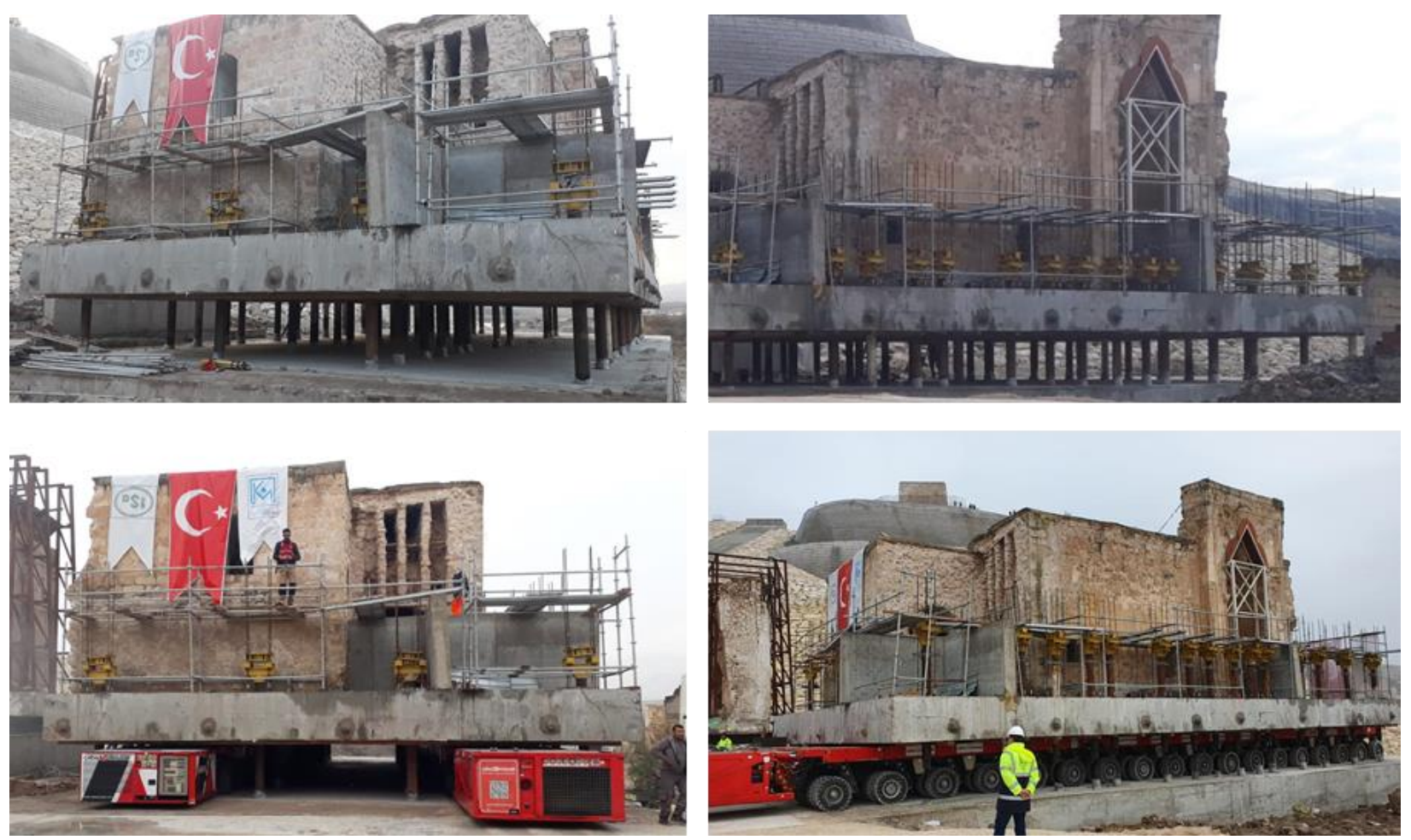

Resim 11. Hasankeyf Er Rızk Camii Revaklı Mekân Kütlesi Strüktürel Bütüncül Taşıma Projesi Kaldırma Kriko Sistemininyle Kaldırılması ve SPTM taşıyııı platform üzerine Alınması (ER-BU İnşaat Tic. Aş. arşivi) . 

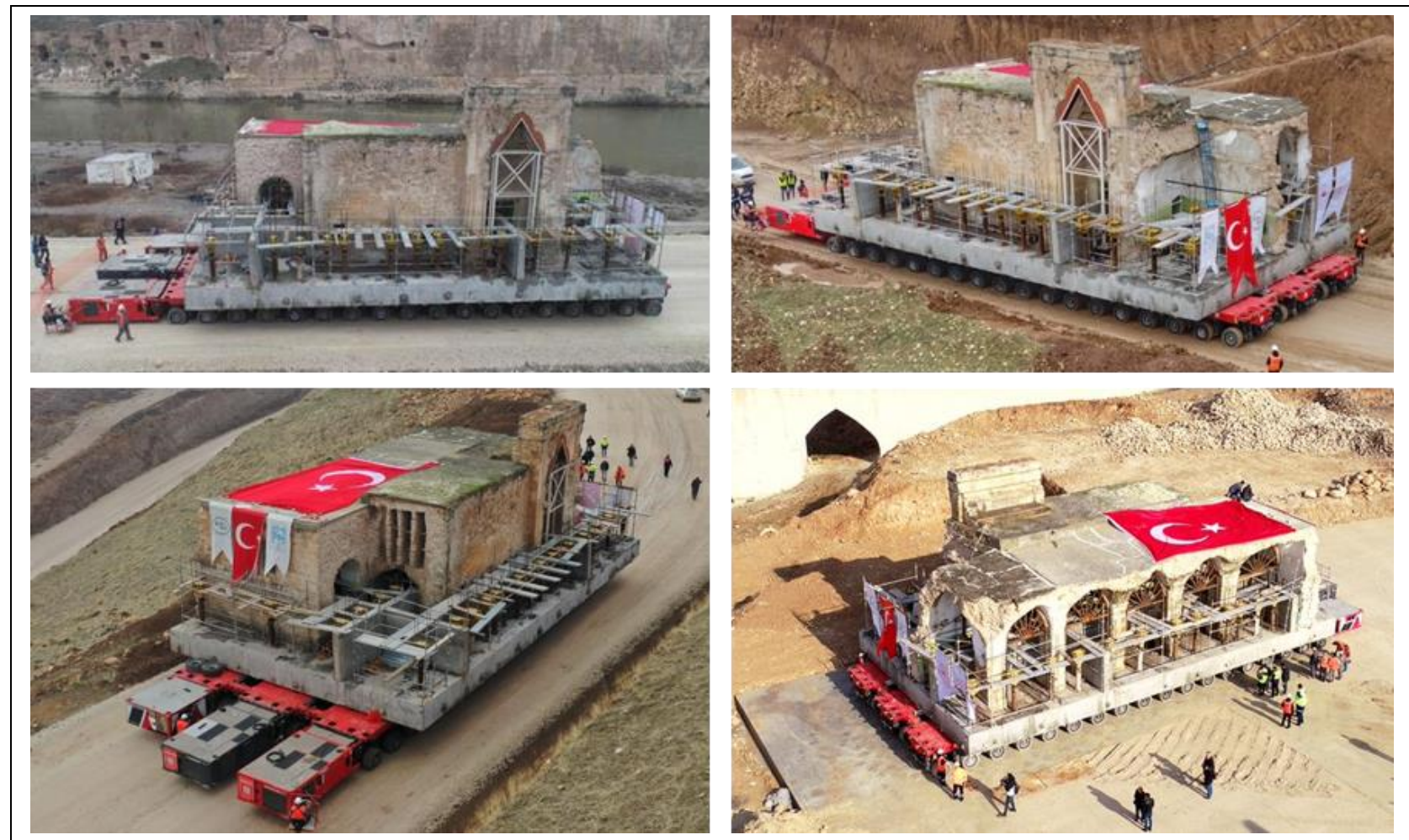

Resim 12. Hasankeyf Er Rızk Camii Revaklı Mekân Kütlesi Bloğu Strüktürel Bütüncül Taşıma Projesi Kapsamında 22Akslı 3 Sıradan (Toplam 66 Aks) Oluşan SPTM Taşıııı Platform Üzerinde Arkeoark Alanındaki Yeni Konumuna Taşınması (ER-BU İnşaat Tic. Aş. arşivi).
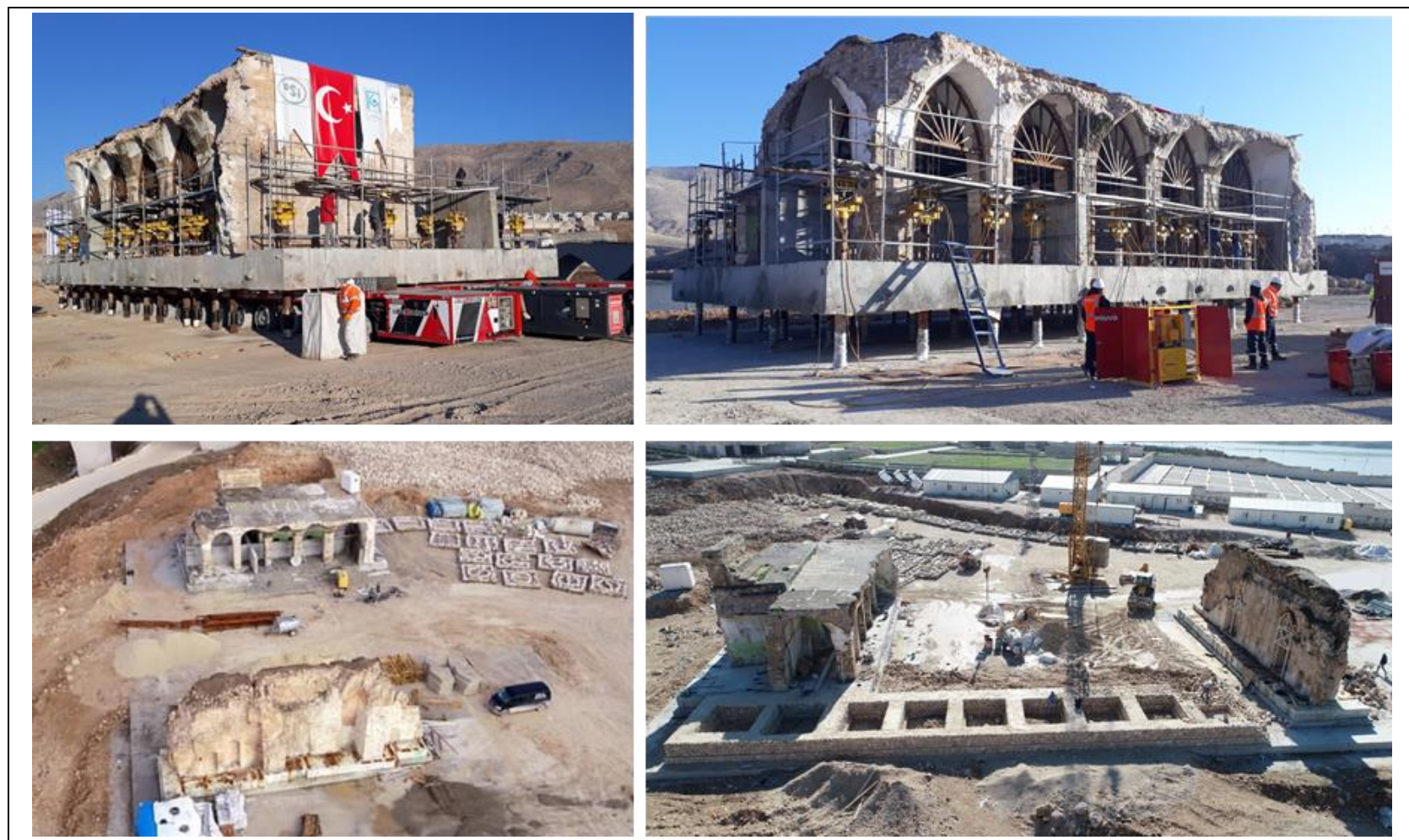

Resim 13. Hasankeyf Er Rızk Camiinin Arkeoark Alanındaki Yeni Konumunda Yeniden Kurulum, Montaj, Restorasyon ve Sergileme Çalışmaları (ER-BU İnşaat Tic. Aş. arşivi). 

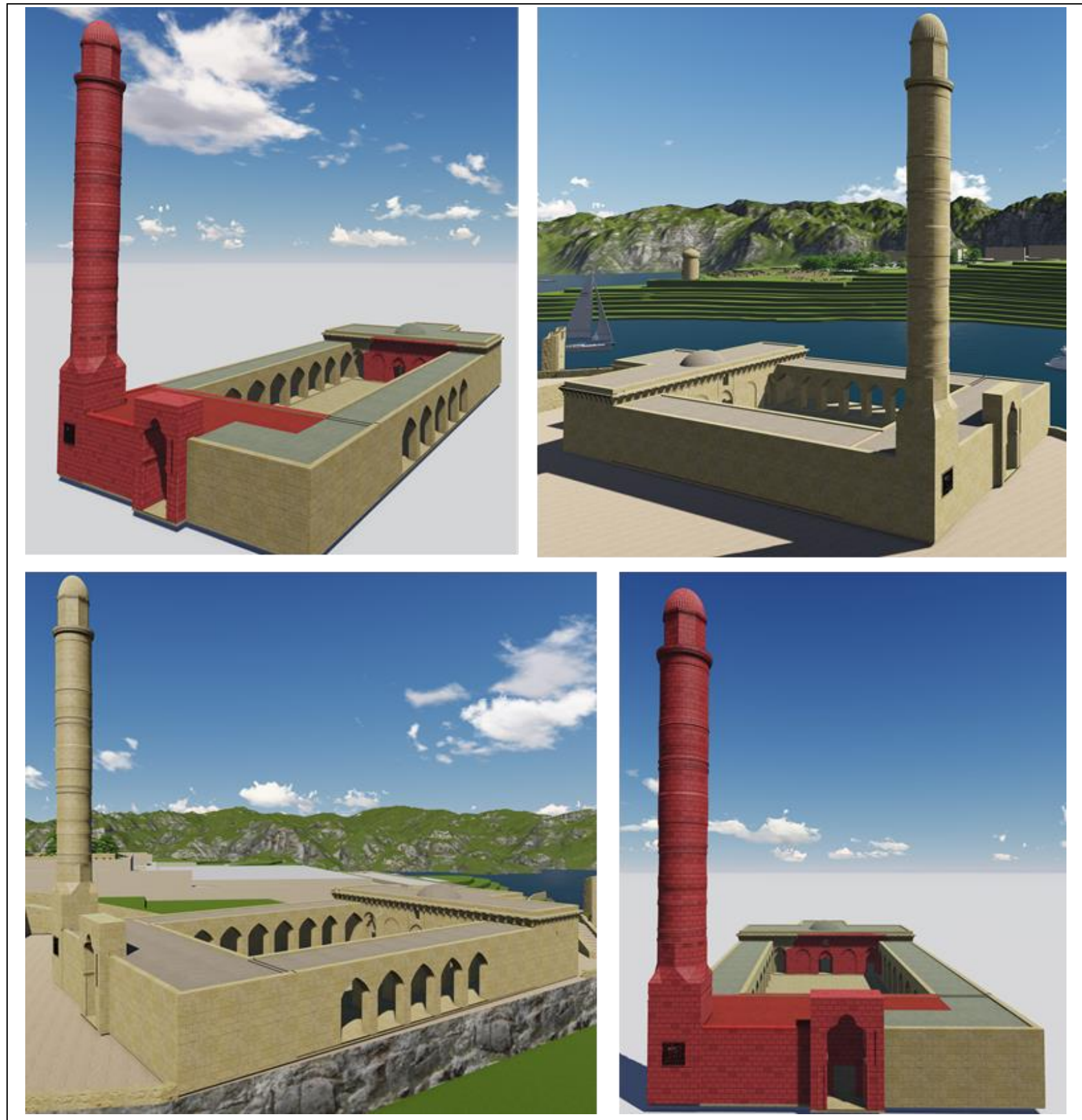

Resim 14. Hasankeyf Er Rızk Camiinin Arkeoark Alanındaki Yeni Konumunda Restorasyon ve Sergileme Çalışmaları Sonrası Durumunun Üç Boyutlu Model Çizimi Görselleri. 